\title{
ARTICLES
}

\section{The Decisions No. 348 and $349 / 2007$ of the Italian Constitutional Court: The Efficacy of the European Convention in the Italian Legal System.}

\author{
By Francesca Biondi Dal Monte and Filippo Fontanelli*
}

\section{A. The Importance of the Rulings Commented in the Framework of the Protection of Fundamental Rights in a Multilevel Legal Order}

For the first time, national provisions governing the quantification of respective compensation amounts due for public purposes expropriation and for unlawful expropriation ${ }^{1}$ were declared unconstitutional by the Italian Constitutional Court's decisions No. 348 and 349, issued on 24 October 2007,2 because they were in contrast with the international obligations stated in Protocol 1 of the European Convention of Human Rights (hereinafter the "ECvHR"), Article 1.

After these decisions were drawn, the relationship between European Courts on the protection of fundamental rights has undergone a significant evolution. Not only has the Italian Constitutional Court clarified, through Article 117 paragraph 1 of the Italian Constitution, ${ }^{3}$ the European Convention's actual efficacy in the domestic legal system, but it has interpreted international obligations as an interposed standard of review, on the basis of which the constitutionality of domestic law must be assessed.

\footnotetext{
* The writing of this essay was divided between the authors but the end result is a joint whole. The authors are also jointly responsible for any errors. In particular, Francesca Biondi Dal Monte (francesca.biondi@unife.it), Ph.D Candidate in Constitutional Law at the University of Ferrara, wrote paragraphs No. 1, 2, 3, 7 and 9; Filippo Fontanelli (f.fontanelli@sssup.it), Ph.D Candidate in Individual person and legal protections at Sant'Anna School of Advanced Studies, Cleary Gottlieb Steen \& Hamilton LLP, wrote paragraphs 4, 5, 6, 9, 10 and 11. We would like to thank Giuseppe Martinico for his precious assistance. All translations from an original Italian text (including the decisions commented) are ours. The usual disclaimer applies.
}

${ }^{1}$ By this term we mean the phenomenon of acquisition by right of occupancy (occupazione acquisitiva), which occurs when the State gets the property of an expropriated land, not in force of a proper expropriation order, but by building public facilities on it.

${ }^{2}$ All the decisions of the Italian Constitutional Court are available at www.cortecostituzionale.it.

${ }^{3}$ As amended by the constitutional law No. 3 of 2001. 
The Constitutional Court tackled a delicate issue: on one hand it had to prevent the sanctions, inevitable at the time, that the European Court of Human Rights (hereinafter, the "ECtHR") would inflict on Italy if the domestic legislation on expropriation were not to change, on the other hand it wanted to prevent another trend, that of the potential shift of the primary forum for individuals' claims from the national to the international jurisdiction. ${ }^{4}$

In the last years, the ECtHR has often condemned and asked Italy to remove any (normative) obstacle that prevented dispossessed owners from receiving a reasonable compensation in relation to the market value of the land expropriated. ${ }^{5}$ The Strasbourg Court, indeed, because of the guilty inactivity of the Italian legislator, had already started to admit actions brought by Italian citizens although they had not previously exhausted the domestic legal proceedings available: ${ }^{6}$ by doing this, the Court implicitly condemned the Italian remedies, since, in its view, the Italian regulation as a whole did not comply with the ECvHR's requirements, and therefore the ineffectiveness of the remedies offered made Article 35 of the Convention inapplicable. ${ }^{7}$

4 See the report compiled by the Italian House of Deputies (Camera dei Deputati) on the web site http://www.camera.it/europ_rap_int/14489/20513/14494/documentotesto.asp (2007) and http://www.camera.it/ europ_rap_int/14489/20513/14495/documentotesto.asp (2006) where the sanctions inflicted to Italy by the Court of Strasbourg in the last two years are referred to.

${ }^{5}$ See Scordino v. Italy, May 29, 2006. For a careful overview of the ECtHR's case-law on this issue (and in particular of the decision Jahn and Others v. Germany, No. 46720/99; 72203/01; 72552/01), and for a description of the effects of this jurisprudence in Germany see U. Deutsche, Expropriation without Compensation - the European Court of Human Rights sanctions German Legislation expropriating the Heirs of "New Farmers", 6 GERMAN LAW JOURNAL 1367 (2005).

${ }^{6}$ As requested instead under Article 35, para. 1, of the ECvHR.

7 Artcile 35, paragraph 1 reads: "The Court may only deal with the matter after all domestic remedies have been exhausted, according to the generally recognised rules of international law, and within a period of six months from the date on which the final decision was taken." The domestic remedy, however, needs to be effective, see Exhaustion of Domestic Remedies, from the ECtHR Key case-law issues series, available at the Court's website (http://www.echr.coe.int/NR/rdonlyres/E3FC0C7E-BD11-479FB069-C300449B7ECF/0/COURT_n1295989_v2_Key_caselaw_issues_Art_35_para_1_Exhaustion_

of_domestic_remedies2.pdf), § 10: “In determining whether any particular remedy meets the criteria of availability and effectiveness, regard must be had to the particular circumstances of the individual case. Account must be taken not only of formal remedies available, but also of the general legal and political context in which they operate as well as the personal circumstances of the applicant (Van Oosterwijck $v$. Belgium, judgment of 6 November 1980, §§ 36-40; Akdivar v. Turkey, judgment of 16 September 1996, §§ 68-69; Khashiyev and Akayeva v. Russia, judgment of 24 February 2005, §§ 116-117; Isayeva and Others v. Russia, judgment of 24 February 2005, §§ 152-153)." In addition, see A. Guazzarotti, La CEDU e l'ordinamento nazionale: tendenze giurisprudenziale e nuove esigenze teoretiche, XXVI QUAD. COST. 497 (2006). The Author here mentions, among others, the cases Scozzari and others, No. 67790/01; Serrilli, No. 77822/01; Binotti No. 2, No. 71603/01. 
In addition to that, the decisions discussed here eventually examined the "disapplication" phenomenon; specifically, its occurrence in conflicts between domestic law and the ECvHR. Some judges had already started applying this method, which comes from the judicial practice of disapplying the internal statutory norm conflicting with Community law. In some recent occasions, even the Supreme Court of Cassation (Corte di Cassazione) and the Supreme Administrative Court (Consiglio di Stato) had endorsed the use of disapplication in cases of conflict with ECvHR law.

With regard to the single referrals, the Constitutional Court in decision No. 348 stated the unconstitutionality of Article 5-bis, paragraphs 1 and 2, of the Law Decree (decreto legge) No. 333 of July 11, 1992, converted into law (in an amended version) by Law No. 359 of August 8, 1992, concerning the criteria for calculating compensation in case of expropriation for public purposes, ${ }^{8}$ and the application of these calculation criteria to pending cases, following the entry into force of Law No. 359 of $1992 .{ }^{9}$

Instead, Article 5-bis, paragraph 7-bis, of the said July 8, 1992, Law Decree No. 333, which set the criteria of compensation for unlawful expropriation, ${ }^{10}$ was declared unconstitutional by the Constitutional Court's No. 349 decision.

In particular, the Italian regulations challenged were in conflict with Article 117, paragraph 1 of the Constitution, in relation with the European Convention's First Protocol, Article 1, because they did not provide significant compensation in case of unlawful expropriation and expropriation for public purposes. ${ }^{11}$ The abovementioned criteria set to calculate the compensation, indeed, represented an infringement of the basic property right, thus, being in conflict with the Conventional norms that protect it.

8 The sum obtained is based on the average between the market value and the reappraised rental income (reddito dominicale rivalutato).

${ }_{9}^{9}$ This constitutional plea was introduced incidentally (in via incidentale) before the Constitutional Court through three separate referral orders issued by the Supreme Court of Cassation: one on May 29, 2006, and two on October 19, 2006, respectively registered in the 2006 orders' register at No. 402 and 681, and in the 2007 orders' register No. 2.

10 This constitutional question was pledged before the Court with the referral orders issued by the Supreme Court dated May 20, 2006, and by the Palermo Court of Appeal on June 29, 2006, respectively registered in the orders' 2006 register of the Court at No. 401 and 557.

${ }_{11}$ As for expropriation for public purposes, the conflict arises only when the public interest pursued is not of a fundamental nature. 
Moreover, the judges challenged the domestic discipline on the grounds of its contrast with Article 111, paragraphs 1 and 2, of the Constitution, and with its interpretation based on Article 6 of the European Convention. These norms, indeed, provide for the application to pending cases of the new unfavorable compensation's calculation criteria in case of both unlawful expropriation and expropriation for public purposes, therefore, they violate the rules of due process, namely the principle of equality of arms. As a result, the legislator's intervention in the field of justice administration causes damage to the plaintiffs, since it aims at regulating a particular and circumscribed set of disputes' outcomes.

The grounds of the two judgments are virtually undistinguishable, therefore, unless otherwise specified, we will refer to them as one single decision. ${ }^{12}$

\section{B. The ECtHR Case-Law on Lawful and Unlawful Expropriation: The Divergence With the Italian Constitutional Case-Law}

Before analyzing the merit of the unconstitutionality decisions, it is necessary to outline the normative and judicial framework they are rooted in, which is either implicitly or expressly referred to. The orders, invoking the Article 111 and 117 standards, were declared non-manifestly inadmissible because of the potential violation of ECvHR's Article 6 and ECvHR's Protocol No. 1, Article 1, as interpreted by the ECtHR.

With regard to lawful expropriation, the referring judges recalled the July 29, 2004 ECtHR's decision (Scordino v. Italy). In this decision, the Strasbourg Court censored Italy's conduct, namely the application of said Article 5-bis to ongoing trials; such retroactive effect of the provision was prejudicial both to the clarity and certainty of the normative discipline governing dispossessing practices, and to the property rights of dispossessed individuals. Indeed, the application to ongoing disputes of the criterion set by Article 5-bis violated the expectations of expropriated individuals who had filed a claim with a tribunal in order to get a compensation calculated upon the goods' market value, as pursuant to June 25, 1865 Law, No. 2359, Article 39, regulating expropriation for public purposes. This statute was put back into force after another set of norms, that provided for a compensation equaling the agricultural/rural value of the land were declared unconstitutional.

12 Two different judges wrote the two decisions. Justice Gaetano Silvestri wrote decision No. 348, whereas justice Giuseppe Tesauro wrote decision No. 349. 
The ECtHR's decision, dated March 29, 2006, instead, ascertained the systematic violation of Protocol No. 1 Article 1 perpetrated by Italy, and stated that the constant use of compensation's quantification criteria that unreasonably disregarded the actual goods' market value had determined, as said, a structural situation of violation of human rights. ${ }^{13}$ Furthermore, the Strasbourg Court highlighted that Italy, under Article 46 of the Convention, had an obligation to put such a situation to an end, through the adoption of suitable legislative, administrative, and economic measures.

In the European Court's view, in fact, the interference with the right to the peaceful enjoyment of possessions must strike a "fair balance" between the community's general interest demands and the individual's fundamental rights protection requirements. ${ }^{14}$ The Court claims that: "the concern to achieve this balance is reflected in the structure of Article 1 as a whole, including, therefore, the second sentence, which is to be read in the light of the general principle enunciated in the first sentence. In particular, there must be a reasonable relationship of proportionality between the means employed and the aim sought to be realized by any measure applied by the State, including measures depriving a person of his possessions." 15

In determining whether this requirement is met, the Court acknowledges that the State enjoys a wide extent of discretionary powers on both choosing the means of enforcement and ascertaining whether the consequences are justified in the general interest for the purpose of achieving the object of the law in question. ${ }^{16}$

Moreover, according to Protocol 1, Article 1, the right to full compensation is not always guaranteed. Although in many cases of lawful expropriation only full compensation in relation to the property value can be regarded to as reasonable (for instance in case of land expropriation for the purpose of building a road or for

\footnotetext{
13 See Scordino 2006, § 82: “Having regard to the margin of appreciation Article 1 of Protocol No. 1 allows national authorities to choose the opportune balance; the Court considers that the price paid to the applicants did not bear a reasonable relation to the value of the expropriated property (see Papachelas v. Greece [GC], no. 31423/96, § 49, and Platakou v. Greece, no. 38460/97, § 54). It follows that the fair balance was upset." On the Scordino case, see also S. Mirate, Scordino ultimo atto: la Corte europea torna a "condannare" l'occupazione acquisitiva e indennizza al valore attuale il terreno occupato, in 88 RESPONSABILITÀ CIVILE E PREVIDENZA, 2007, 1053 and $\mathrm{ff}$

${ }^{14}$ See Lönnroth v. Sweden, No. 7151/75; 7152/75 § 69.

${ }^{15}$ See Pressos Compania Naviera S.A. and Others v. Belgium, No. 17849/91, § 38; The former King of Greece and Others v. Greece [GC], No. 25701/94, §§ 89-90.

16 See Chassagnou and Others v. France [GC], No. 25088/94, 28331/95 and 28443/95, § 75.
} 
other purposes related to the "the public interest"), this rule is subject to some exceptions. ${ }^{17}$

Indeed, legitimate objects pursued in the "public interest," such as those pursued through economic reform measures or through measures designed to achieve greater social justice, may call for less than the reimbursement of the full market value. For example, in the case of James and Others $v$. The United Kingdom ${ }^{18}$ the issue was whether, in the context of the leasehold-reform legislation, the conditions that empowered long-term leasehold tenants to acquire their property struck the fair balance. The European Court found that they did, holding that the context was one of social and economic reform in which the burden borne by the freeholders was not unreasonable, even though the amount received by the plaintiffs was less than the property's full market value. ${ }^{19}$

On the contrary, the Italian norms governing compensation in case of expropriation for public purposes had already undergone the constitutionality test before the Constitutional Court several times, and they had been declared consistent with Article 42, paragraph 3, of the Constitution, since they introduced a well-thought criterion, which guaranteed a "non ridicule" indemnity to the expropriated individuals. In this sense, the provisions duly suited the property's social function in the Italian legal order (see decision No. 283/1993, order No. 414/1993, decision No. 442/1993).

\footnotetext{
${ }_{17}$ See James and Others $v$. The United Kingdom, No. 8793/79, § 54, Broniowski v. Poland [GC], No. 31443/96, $\S 182$, The Former King of Greece and Others v. Greece [GC] (just satisfaction), No. 25701/94, § 78.

18 Chassagnou, supra note 16.

19 The Court has held that less than full compensation may also be necessary, a fortiori, where property is taken for the purposes of "such fundamental changes of a country's constitutional system as the transition from monarchy to republic." See The Former King of Greece, cited above, § 89. The Court has gone over this principle again in the case of Broniowski v. Poland, in the context of the country's transition towards a democratic regime, and has specified that rules regulating ownership relations within the country "involving a wide-reaching but controversial legislative scheme with significant economic impact for the country as a whole" could involve decisions restricting compensation for the taking or restitution of property to a level below its market value. The Court has also reiterated these principles regarding the law's enactment in "the exceptional context of German reunification." See Von Maltzan and Others v. Germany (dec.) [GC], nos. 71916/01, 71917/01 and 10260/02, §§ 77 and 111-12. In the Papachelas $v$. Greece case ([GC], No. 31423/96), in which the issue concerned more than 150 properties' expropriation, including part of the applicants' property, for the purpose of building a major road, the Court held that the compensation awarded to the applicants had not upset the fair balance between opposing interests as it was just slightly lower than the certified value of the land.
} 
As for the application to ongoing trials, the Court had rejected the claims of unconstitutionality, since outside the sector of criminal law the general principle of non-retroactivity is of a non-constitutional nature..$^{20}$

Even the referrals questioning the constitutionality of unlawful expropriation made reference to the ECtHR's case law on Protocol 1, Article 1, and to its evolution towards a stronger protection of property rights.

In the ECtHR's view, indeed, the Italian practice violated the property right, since it was deprived of a legal basis, and, therefore, made it impossible to foresee the legal outcome of an unlawful expropriation procedure. ${ }^{21}$ Among the reasons for stating the incompatibility, the European Court listed the criterion used to quantify the compensation, maintaining that the reduced amount obtained following that criterion set a further advantage for the Public Administration accountable for the unlawful conduct. In other words, the State would be waived from paying a significant part of the due indemnity, and this could lead to misbehaviours and episodes of unlawful conduct by the Public Administration.

Moreover, the Court stated that, by setting an unlawful expropriation compensation, which was only slightly higher than the compensation provided in case of lawful expropriation, the discipline could lead to a violation of the property right protected by the Convention. ${ }^{22}$

On the domestic side, again, the Constitutional Court had already intervened on the matter, and had stated the unconstitutionality of Article 5-bis, paragraph 6, for violating Article 3, 28, 42, paragraph 2, and 97 of the Constitution. The provision was unconstitutional in setting the compensation criteria for unlawful expropriation in appliance of the same criteria set by the public purposes' lawful expropriation's discipline.

Indeed, in the case of unlawful expropriation, the public interest is satisfied by the non-restitution of the good seized, followed by the transfer to the State of both its property and the property of the public buildings on it. Under the principle of

\footnotetext{
${ }^{20}$ On the divergences existing between Italian constitutional case-law and the Court of Strasbourg's jurisprudence see F. Scoca, Indennità di espropriazione: la diversa sensibilità della Consulta e della Corte di Strasburgo, available at: www.federalismi.it, May 31, 2006.

${ }^{21}$ See Belvedere-Alberghiera v. Italia, No. 31524/96, Colazzo e Serrao v. Italia, No. 63633/00, Sciarrotta $v$. Italia, No. 14793/02; Immobiliare Cerro S.A.S. v. Italia, No. 35638/03).

22 See among others, Immobiliare Cerro No. 35638/03, Scordino v. Italy No. 3, No. 43662/98, Pasculli v. Italy, No. 36818/97.
} 
reasonableness, the equalization of the compensation criteria is excessively favourable to the public interest making it unsuitable since it alters the balance struck between conflicting public and private interests (see decision No. 369/1996).

However, the following legislator's intervention had only slightly increased the amount due for compensation (Article 3, paragraph 65 of Law No. 662 of 1996) that, nevertheless, continued to be far lower than the actual market value. This norm applied retroactively as well, and affected all the ongoing trials in which individuals had filed a claim for compensation.

Several issues of constitutionality had been raised since then, but all of them were rejected: the Court has repeatedly maintained that if a public interest backs the unlawful expropriation procedure, there is no constitutional obligation that guarantees full compensation of the damages suffered, or that excludes the trials in course from the re-calculation of the compensation (see decisions No. 148/1999; $396 / 1999$ and 24/2000, and orders No. 251/2000 and 158/2002).

Bearing these facts in mind, the referring judges challenged the provisions on the basis of the different standard of review of Article 111 and 117, paragraph 1, of the Constitution. They introduced a new perspective, alleging the challenged norm's supervened conflict ${ }^{23}$ both with the principle of fair trial and with the international obligations adhered to by Italy, in reference to the ECvHR's Article 6 of and to the ECvHR's Protocol Number 1, Article 1, working as interposed standards.

\section{The Reasoning of the Court and the Use of Article 117, Paragraph 1, of the Constitution}

The Constitutional Court ruled that the issues submitted were grounded on the basis of Article 117, paragraph 1 of the Constitution, which reads: "Legislative powers shall be vested in the State and the Regions in compliance with the Constitution and with the constraints deriving from EU-legislation and international obligations."

The content of Article 117, paragraph 1 of the Constitution, introduced after the 2001 constitutional reform, was the subject of a strenuous debate between scholars, probably due to its concise and insufficiently articulated wording. ${ }^{24}$ Some scholars

\footnotetext{
23 This change of circumstances followed the abovementioned 2001 constitutional reform and the introduction of the new Article 117, para. 1, of the Constitution.

${ }_{24}$ On this point see R. Bin, Le potestà legislative regionali dalla Bassanini ad oggi, in LE FONTI DEL DIRITTO REGIONALE ALLA RICERCA DI UNA NUOVA IDENTITÀ 140 (A. Ruggeri, G. Silvestri eds., 2001).
} 
argued that the position of this provision in the Constitution's structure ${ }^{25}$ proved that it could refer only to the relationship among sub-national legal orders that supplement the Italian Republic (Regions), and that its purpose was not that of governing their respective sources' hierarchies. ${ }^{26}$ Others argued that the constitutional reform introduced a new mechanism, under which the norms implementing international law obligations in the domestic order can serve as an interposed standard of review. ${ }^{27}$ Therefore, as a consequence of the indirect conflict with Article 117, paragraph 1 of the Constitution, ${ }^{28}$ their violation by a national statutory norm would imply its unconstitutionality.

The Constitutional Court explicitly adheres to the second interpretation, discarding the theory that this provision is just a rephrased edition of pre-existing constitutional norms (namely Articles 10 and 11) and that its efficacy is limited to the State-Regions relationship.

The use of a merely contextual interpretation cannot supersede the literal meaning of the provision, thus, the international obligations' limiting effect on domestic legislation cannot be confined to its domestic side only.

The Court states that the duty to respect and perform international obligations affects univocally and globally the content of domestic legislation, whose validity obviously cannot depend on which point of view is under consideration (the reciprocal limitation of competences between State and Regions, rather than the extent of State legislative power as a whole). ${ }^{29}$

${ }^{25}$ Namely Article 117 is in part V of the Constitution, called Le Regioni, le Province, $i$ Comuni.

${ }^{26}$ See C. Pinelli, I limiti generali alla potestà legislativa statale e regionale e di rapporti con l'ordinamento internazionale e comunitario, 126 FORO ITALIANO 194 (2001); E. Cannizzaro, La riforma federalista della costituzione e gli obblighi internazionali, 96 RIVISTA DI DIRITTO INTERNAZIONALE 921 (2001).

27 In general, on the interposed provision's mechanism, see M. Siclari, LE NORME INTERPOSTE NEL GIUDIZIO DI COSTITUZIONALITÀ (1992). The scholars have minted the wording "interposed provision" to individualize the cases in which a constitutional standard can be invoked only indirectly in a constitutional judicial proceeding, because different primary provisions are inserted between the constitutional standard and the reported provisions (suspicious of being unconstitutional). See also, M. Siclari, La tecnica delle norme interposte, 133 FORO ITALIANO 337 (1998) (in which he recalls an old precedent of the Italian Constitutional Court, decision No. 46 of 1961, referred to the Convention of Paris, dated September 5, 1946, between Italy and Austria).

28 See, among others, A. Guazzarotti, La CEDU e l'ordinamento nazionale: tendenze giurisprudenziali e nuove esigenze teoretiche, 26 QUAD. COST. 505 (2006); M. Cartabia, La CEDU e l'ordinamento italiano: rapporti tra fonti, rapporti tra giurisdizioni, in ALL'INCROCIO TRA COSTITUZIONE E CEDU, IL RANGO DELLE NORME DELLA CONVENZIONE E L'EFFICACIA INTERNA DELLE SENTENZE DI STRASBURGO 11 (R. Bin, G. Brunelli, A. Pugiotto, P. Veronesi eds., 2007).

${ }^{29}$ See decision No. 348, para 4.4 . 
In particular, the standard set by Article 117, paragraph 1, can act only if the "international obligations" limiting state and regional normative power are defined: its role is to supplement, in the facts, the theoretical concept of "international obligation." The new Article 117, paragraph 1, in keeping with the constitutional charts of other European countries, filled a gap in the set of instruments and "principles that already guaranteed the respect of certain international obligations contracted by the State" at an ordinary level, as it permits a "shifting referral to treaty law relevant from time to time, that enlivens and gives body to those international obligations that are only generically referred to." 30

This cannot imply that international treaty norms, including ECvHR norms, could bear a constitutional value and could, therefore, be free from any constitutional control; the judges defined their rank by referring to a new "intermediate source." The ordinary judge has to draw the domestic provision consistently with the international provision, as far as allowed by the literal meaning of the norms regulating such an activity. The Court argued that, were this operation infeasible, or in case the judge had doubts on the international norm's constitutionality, a conflict between a statutory norm and a conventional norm would give rise to a constitutionality issue on the basis of a potential violation of Article 117, paragraph 1 , and such a conflict would be exclusively up to the competence of the constitutional judge to decide. ${ }^{31}$

Decision No. 348 clarified the standard of review's nature. With it the Court decided to perform the constitutionality test in two phases. First, it checked whether it was possible to identify an unsolvable conflict between the challenged provision and the ECvHR norm, as interpreted by the ECtHR, and whether such a conflict could be composed by an adapting interpretation. Second, the Court verified whether the ECvHR norms, integrating the standard of review, were compatible with the Italian constitutional order. ${ }^{32}$

To do so, the Court took all relevant ECtHR case law under consideration, since "ECvHR law lives in the interpretation given by the ECtHR on it," and because the constitutionality test's object is to view the norm as the product of an interpretation activity, rather than just the provision in itself.

\footnotetext{
${ }^{30}$ See decision No. 349, para 6.2.

${ }^{31}$ See decision No. 349, para 6.2, and No.348, para 4.7.

32 See decision No. 348, para. 4.7 and 5.
} 
The Court investigated the rationes decidendi of the two case laws (its own and the ECtHR's), and found out that the Italian and European Courts had, allegedly, followed a similar argumentation: ${ }^{33}$ the dispossessed owner's property right can be partially sacrificed for public interest purposes, thus, the compensation offered must not necessarily equal the good's market value, although it has to represent a significant compensation for the owner. The diverging outcome reached by the two case laws was due, in fact, to the different conceptions of the significance of the compensation offered by the Public Administration. Whereas the provisions contained in the Constitution are vague enough to permit a lower refund, the $\mathrm{ECvHR}$ is clear in its request for a significant reimbursement; moreover, the criteria set by domestic regulation in order to quantify the compensation were justified at the time of their adoption by their transitory nature, and by the serious economical situation that Italy was facing.

As for the time being, the Court notes that the then provisional criterion was given stability by June 8, 2001 presidential Decree, No. 327, Article 37; therefore one of the reasons for conceding provisional constitutionality to the norm ceased to exist, since it could not be maintained that a state of crisis "can last forever, therefore conferring the legislation a nature of everlasting exceptionality." Hence, a significant and suitable compensation "cannot take the market value as merely a starting parameter, on which further modifications intervene, based on elements that are totally extraneous to the good's value." Whilst the rental income's (reddito dominicale) value still bears a connection, albeit weak, with the market value, a further decrease of $40 \%$ is deprived of any ground, except for a purely arithmetic one, concerning the good's value. ${ }^{34}$

In sum, the challenged provision, setting an indemnity having a value equal to between $50 \%$ and $30 \%$ of the land's market value, fails the constitutionality test with regard to the "reasonable relation" with the market value, which is a condition required by the Strasbourg Court's case law and which is also consistent with the "significant refund" (serio ristoro) condition set in the same Constitutional Court's case law. ${ }^{35}$

33 On the tendency of the Constitutional Court to underline the common points between its jurisprudence and ECtHR's jurisprudence, as a first step of dialogue between the two Courts, see C. Napoli, La nuova collocazione della CEDU nel sistema delle fonti e le conseguenti prospettive di dialogo tra le Corti, 28 QUADERNI COSTITUZIONALI 139 (2008).

${ }^{34}$ See decision No. 348, para. 5.6.

${ }^{35}$ As the Court, itself, states: "this compensation is below the minimum threshold of acceptability for an indemnification granted to dispossessed owners, as the even limited amount offered is further diminished because of taxes equaling - as the claimant notes - the level of about 20 per cent. The due 
The Court maintains that the legislator is not forced to provide for the equivalence between the compensation and the market value: in fact, the Article 42 of the Constitution acknowledges and protects property rights, emphasizing its social purpose, which "the legislator and the interpreters must assure in relation with Article 2, which calls for the performance of imperative duties of economic and social solidarity by every citizens."

Furthermore, the judges maintain that "excessively high expenditure standards connected with the expropriation of building areas for public purposes could seriously jeopardize the effective safeguard of several fundamental constitutional rights (such as health protection, a right to education, a right to housing, etc.), moreover, these standards could hamper the implementation of public facilities needed to strengthen the exercise of private enterprise."

Thus, it is up to the legislator to assess whether the balance between the private interest and the property's social purpose "has to be fixed and unvarying or, according to ECtHR's guideline, it has to be struck in a mutable way, depending on the qualification of the public interest purposes pursued." Nevertheless, single expropriations carried out for limited interest purposes cannot be incorporated to big expropriation plans intended to facilitate economic reform planned interventions, or to foster better social justice conditions.

Likewise, in Decision No. 349, the Constitutional Court reassessed both its own case-laws and the ECtHR's in order to collect useful material to its task, i.e. the constitutional control over the criteria set to calculate compensation for unlawful expropriation. The Court took avail of this retrospective analysis in mentioning the reasons that led it to find such provisions constitutional under Articles 3 and 42 of the Constitution in the past.

More specifically, the Court remarked on the lack of constitutional support for the criterion providing full compensation for damages, on the "exceptional nature of the case," due "mainly to the provisional nature of the challenged provision," and on the need to safeguard an unavoidable and transitory public recovery plan. ${ }^{36}$

However, the constitutional judges observed that the balance struck in the past, with reference to other review standards, should now be struck bearing in mind the

sacrifice that public interest can demand cannot end up by consisting in the virtual nullification of the good possessed" (decision No. 348, para. 5.7).

${ }^{36}$ See Italian Constitutional Court decisions No. 148/1999 and No. 24/2000. 
importance of the international obligations undertaken by Italy's. That is, the criterion setting a lower compensation than the good's market value enters into conflict with the norm of ECvHR's Protocol 1, Article 1, as interpreted in wellestablished case law. Therefore, the Italian regulation on this matter is incompatible with Article 1 and, consequently, with the new Article 117, paragraph 1 of the Constitution.

In light of this new standard of review, the Court stated that the Italian rule could not represent a valid alternative to the requirements set by the $\mathrm{ECvHR}$, not even in the framework of the Italian constitutional principles.

However, we must specify that the change in the circumstances played a different role in the decisions being assessed. In decision No. 348, indeed, the alteration occurred could have led the Court to abandon the position held in the past and to state the unconstitutionality of the challenged norm on the basis of Article 42 of the Constitution since the circumstances that had prevented the conflict from being ascertained were no longer occurring. On the other hand, the norm under consideration in decision No. 349 had a mere retroactive effect, ${ }^{37}$ therefore, the constitutionality decision supported by the "circumstantial" argument would have had a permanent effect (this norm applies to past facts only, and a crisis was occurring at the time of these facts), rather than a provisional one. It is hard to understand how the Italian Court could now appeal to the change of circumstances as a valid cause to overturn its precedent. It is obvious that the position held by the Strasbourg Court played a major role in convincing the Italian Court to rethink its case law. ${ }^{38}$

\footnotetext{
${ }^{37}$ It applied to unlawful expropriations carried out before September 30, 1996.

38 On this point, see A. Guazzarotti, La Corte e la CEDU: il problematico confronto di standard di tutela alla luce dell'articolo 117, co. 1, Cost, 53 GIURISPRUDENZA COSTITUZIONALE (forthcoming 2008), who also underlines that, in its decision No. 349/2007, the Italian Court borrows one of the main arguments the ECtHR had used to blame the practice of unlawful expropriation, namely the "need for granting the administrative action's legality and the public officers' liability principle for damages to third parties." This reasoning apparently counters the position adopted by the Italian Court in the decision No. 148/1999, in which it denied that Articles 28 and 97 of the Constitution could be standards of review for the challenged provisions on unlawful expropriation constitutionality. In fact, this ambiguity is due to a bigger divergence between the Constitutional Court's case law and the ECtHR's, as regards the potential use of the social function of property to counterbalance the otherwise neat rule whereunder only lawful expropriations or full compensation are admitted. According to the Constitutional Court's case law, indeed, the social function (as pursuant to Article 42 of the Constitution) could justify the property deprivation suffered by an individual due to unlawful expropriation procedures, provided that the buildings on the land are of some public interest. On the contrary, the ECtHR maintains that it is not even possible to access the stage of balancing private and public interests when the expropriation lacks a legal justification (as it is in the case of acquisition by right of occupancy's Italian practice (occupazione acquisitive)).
} 
Less than a month after the date of these decisions, the domestic legislator adopted the 2008 budget-law, whereby it modified the criteria of compensation we have examined. In particular, a full compensation (that is, of a value equal to the market price) is due in case of expropriation of building areas, unless the intervention forms part of a wider policy of "socio-economic reform," in that case a $25 \%$ reduction can apply. ${ }^{39}$ Concerning unlawful expropriation (as more fully described above), expropriations stemmed from an expropriation order dated on or before September 30, 1996 must be compensated awarding a sum equalling the market value of the estate (see Article 2, para. 89, of Law December 24, 2007, No. 244). ${ }^{40}$

The Supreme Court already applied these new criteria, in Decision No. 8384 of March 30, 2008, concerning a case of unlawful expropriation, and stated that the change determined by the new provision applies when the calculation of the compensation amount is still under discussion during the trial, and that such amount cannot be higher than the income the owner could gain selling the estate.

This normative intervention has been opportune, as it filled the gap created by the Court's declaration of unconstitutionality. It is, nevertheless, difficult to foresee how ordinary judges will interpret the norm on expropriation for public purposes, as regarding the definition of "socio-economic reforms." The judge now has the task to delimit this definition, in light of the rich case-law of the Strasbourg Court. It will be, in fact, a perfect trial run for the newly clarified (conventionally) consistent interpretation advocated by the Constitutional Court.

\section{The Constitutional Device for International Treaty Law}

In these decisions the Court tries to sum up all the relevant theories concerning the place occupied by international norms within the Italian normative hierarchy in order to get rid of the different interpretations supported by the scholars, based on Article 10 and Article 11 of the Constitution, and to prevent the chosen one from

\footnotetext{
${ }^{39}$ These provisions apply also on currently ongoing expropriation procedures, unless the expropriated owner accepted, or agreed with, the compensation proposal by the Public Authority, or the determination of the compensation has already become irrevocable.

40 See A. Travi, In tema di compatibilità della legge italiana con la Cedu, 133 FORO ITALIANO 41 (2008). The Author stresses how the Court had stated, in the No. 348 decision, that the legislator could adjust the compensation mechanism consistently with Article 42 of the Constitution, without being obliged to provide for the full compensation. On how the Constitutional Court often provides the necessary instruction to implement its rulings, and on the difference existing between the No. 348 and the No. 349 decisions as regards the quantification of the compensation, see L. Cappuccio, La Corte costituzionale interviene sui rapporti tra convenzione europea dei diritti dell'uomo e Costituzione, 133 FORO ITALIANO 50 (2008).
} 
any possible criticism. ${ }^{41}$ This work, albeit useful under a scientific point of view, was ultroneous and somehow unnecessary, since the constitutionality issues were based only on Articles 111 and 117 of the Constitution.

First of all, the Court ruled out the possibility for international treaty law to enter the Italian legal system with the status of a (super) constitutional source under Article 10 of the Constitution, which provides for the "automatic adaptation" of the domestic legal order to the general principles and the customary norms of international law. ${ }^{42}$ In order to dismiss this theory, the Court needs only verify that the norms contained in bilateral or multilateral international treaties are not supported by the extent of Article 10, and that not even the norms bearing a general nature represent an exception.

Here it suffices to recall how the firm rejection of this interpretation prevents the possibility of recalling an impressive theory upheld in the past by a minority of scholars, ${ }^{43}$ according to which Article 10 guarantees the automatic adaptation of Italian law to the well-established international law principle of pacta sunt servanda, among others. This would also imply that Italy must conform automatically to "agreed law," such as international treaties. Furthermore, it is far from certain that the ECvHR does not contain any norm that could be considered of a customary nature: in fact, some of the human rights therein listed are acknowledged by virtually every State of the International Community. ${ }^{44}$

After ruling out the possible application of Article 10, the Court moved on to Article 11 of the Constitution, which allows Italy to accept the sovereignty limitations needed to attain peace and justice in the International Community. 45 Originally conceived to permit the Italian membership in the United Nations, this

${ }^{41}$ For the debate about the position of the ECvHR in the Italian normative hierarchy, see D. Tega, $L a$ Cedu e l'ordinamento italiano, in I DIRITTI IN AZIONE 71 (M. Cartabia ed., 2007). For a specific reference to the constitutional rulings commented here, see S. Bartole, Considerazioni brevi sulle possibili alternative, in AlL'InCROCiO TRA CostituZione E CEDU 27 (R. Bin, G. Brunelli, A. Pugiotto, P. Veronesi eds., 2007).

42 See 349 , para. $6.1 ; 348$, para. 3.4 .

${ }^{43}$ See R. Quadri, DiritTo INTERNAZIONALE PUbBLICO (1956).

${ }^{44}$ See for instance the membership of the UN Convention for the rights of the Child, which totals now 193 members.

45 Article 11 reads: "Italy rejects war as an instrument of aggression against the freedoms of others peoples and as a means for settling international controversies; it agrees, on conditions of equality with other states, to the limitations of sovereignty necessary for an order that ensures peace and justice among Nations; it promotes and encourages international organizations having such ends in view." 
provision has been successively interpreted in order to justify the primacy of EC law over domestic law. 46

The Court, referring to its previous decision No. 188/1980, states that the Council of Europe (hereinafter, the "CoE") (i.e. the legal order in which the European Convention is rooted) lacks the preliminary condition required by Article 11 to have sovereignty limitations permitted and supported by the Constitution, namely, it lacks a full-fledged organizational structure. Moreover Italy has not given up any portion of sovereignty when joining the system of the $\mathrm{CoE}$, and thus it is inappropriate to appeal to Article 11, as there are no limitations at stake. ${ }^{47}$ Although this argument could have been reasonable in 1980, it became debatable after 1998, when ECvHR Protocol XI entered into force "turning upside down" the general system of the ECvHR. ${ }^{48}$ Indeed, it amended the Convention, making the jurisdiction of the ECtHR on individuals' claims compulsory and freeing the Ministers' Committee from the competence to decide the claims on the merits.

Only a continuous comparison between the CoE and the European Union makes the reasoning of the Court fully understandable, so that it is more a question of how much the CoE differs from the EU than a matter of how respondent the former is to the Article 11 test. $^{49}$ A mechanical analysis of the CoE's features would probably lead us to maintain its compatibility with the provision of Article 11. It is not unreasonable to define it as an international organization, furthermore over the years its original features have evolved towards a more constitutional status of the whole institution. The execution of the 1998 Protocol, which is the first evidence of the constitutional process supporting the CoE's action in the field of human rights as well as other recent trends adopted by the Court, seem to confirm this point of

\footnotetext{
${ }^{46}$ See decision 349, para. 6.1.

47 See decision 348 para. 3.3: "this Court had already excluded [even before acknowledging the direct effect of community legislation in 1984] that Article 11 could apply [to ECHR norms], as no limitation to national sovereignty can be envisaged, as concerns the specific treaty law under examination."

48 As A. Guazzarotti notes in his essay, A. Guazzarotti, La Consulta guarda in faccia agli obblighi internazionali e alla CEDU, 14 STUDIUM IURIS 275 (2008). It is worth mentioning that Italy has also ratified the XIV Protocol, that foresees an infringement procedure if a member State does not observe an ECtHR's decision. This mechanism will obviously strengthen the CoE system; the Protocol will enter into force upon full ratification (so far only Russia has not ratified it yet).

${ }^{49}$ See for instance A. Ruggeri, La CEDU alla ricerca di una nuova identità, tra prospettiva formale-astratta e prospettiva assiologico-sostanziale d'inquadramento sistematico (a prima lettura di Corte cost. nn. 348 e 349 del 2007), available at: www.forumcostituzionale.it (noticing that "The Court relies on an old 1980 precedent, to which it explicitly refers, where however the extraneousness of the European Convention to Article 11 was not proven, as it is not proven today.").
} 
view. ${ }^{50}$ Moreover, its competence in the safeguard of human rights obviously contributes to strengthen peace and justice among Nations, as required under Article 11.51 The Court, however, suggests a shifty interpretation of Article 11 of the Constitution by construing it as a description of the Community legal system; a description that the CoE obviously cannot match. ${ }^{52}$

The aforementioned tendentious interpretation is clearly reflected in the passage where the Court states that the Convention "does not set up a supranational legal order, thus it does not produce norms that have a direct applicability in State parties." 53 Moreover, the Court seems to misinterpret the extent of the "limitations of sovereignty" formula, somehow identifying sovereignty (as a whole) with one of its components, normative autonomy; ${ }^{54}$ once again the model envisaged is the EC one. Because of EC exclusive (normative) competence in certain areas, ${ }^{55}$ the Court does not deem the Convention, which indeed limits the discretion and the freedom of the Italian legislator (i.e., it limits its sovereignty), to create a legal order which matches the Article 11 exception. As a final remark, we just remind how the now fully-fledged EC legal order was born indeed as a limited international economic treaty, and thus the choice of the Constitutional Court to use the instrument of Article 11 for its legal justification was, at the time, more debatable than it would be now for the CoE system.

\footnotetext{
${ }^{50}$ Indeed, the Court has started in its decisions, to ask the States not only to redress the single violation ascertained during the trial, but also to adopt structural solutions to avoid its occurrence in the future. This proves that the ECtHR is "constitutionally" concerned in the overall conduct of the State, rather than being just "jurisdictionally" conferred the authority to adjudicate rights in single proceedings.

51 See also the reasoning made by the Court itself in its No.183 decision of 1973, in which the membership to the European Community is fully justified under the terms of Article 11, and the extent of this norm is explained into details.

52 See A. Ruggeri, supra note 49, at 3. The Author explains how the Court interprets Article 11 as a "snapshot norm," which portrays the EC order. This explains why the Court, while verifying the possible application of Article 11, feels the need for reassessing "the distinction between the ECHR norms and community norms" based on the lack of direct effect in the domestic order of the conventional legislation, which is binding on States only.

${ }^{53}$ See decision No. 348, para. 3.3.

${ }^{54}$ See C. Zanghì, La Corte costituzionale risolve un primo contrasto con la Corte europea dei diritti dell'uomo ed interpreta l'art. 117 della Costituzione: le sentenze n. 348 e 349 del 2007, 8, available at: www.giurcost.it.

${ }^{55}$ In other words, the Court confuses limitations of sovereignty, that may be permitted unilaterally by the States, and cessions of sovereignty, that imply a legal order receiving the competence surrendered by the State, like the EU.
} 
Once it outlined the comparison between the Convention and the EC law, the Court moved on to investigate the matter in-depth, and to disprove the possible recognition of ECvHR as part of the EC law. If the ECvHR law were to share the EC nature, in fact, it would also enjoy its supremacy status and would supersede conflicting, ordinary national legislation without any balancing intervention. In the view of the Constitutional Court, the "communitarisation" of the European Convention has not been completed yet, and the fact that Article 6.2 of the TEU counts the Convention among the general principles of community law is not enough to determine its binding force "outside" the field of EC law. As the Court states:

[T] he case-law, indeed, tends to understand fundamental rights as an integral part of the general principles of community law that are enforced by the community judge [...]. Nevertheless, such principles are relevant only in connection with matters to which community law applies: Community acts, domestic acts that execute Community legislation, national derogations to Community law justified by their purpose of promoting the respect of fundamental rights. ${ }^{56}$

The interpretation that the Court gives Article 6.2 recalls the mechanisms codified in Article 51.1 of the Nice Charter, ${ }^{57}$ that of the Charter efficacy's limitation to the implementation of Union law by Member States' bodies.

Human rights, as the Court maintains, do not fall within the Union's competence, therefore the relationship between the CoE system and domestic legal orders "is diversely but steadily regulated within each national system." 58

\footnotetext{
56 See 349, para. 6.1

57 Which reads: "The provisions of this Charter are addressed to the institutions and bodies of the Union with due regard for the principle of subsidiarity and to the Member States only when they are implementing Union law. They shall, therefore, respect the rights, observe the principles and promote the application thereof in accordance with their respective powers."

58 See decision No. 349, para. 6.1. In addition, see the European Court of Justice order C-302/06 of January 25, 2007, František Koval'ský: "De même, la situation des requérant et intervenants au principal ne relève aucunement du champ d'application du droit communautaire. En effet, le juge national n'a pas établi en quoi la situation d'un propriétaire, dont le terrain est occupé par des installations électriques et qui, en contrepartie de cette occupation, demande le versement d'une somme à titre de compensation, peut se rattacher au droit communautaire."
} 
The Court quickly refers to the EU's potential membership to the Convention (a hypothesis set forth in the Constitutional Treaty, and dismissed after its failure), but does not take the trouble of analyzing its consequence on the communitarization of ECHR law in-depth since, at the very time the twin decisions were issued, this seemed a merely theoretical exercise. Instead, just a couple of months after the decisions, the Lisbon Treaty was approved, providing for EU accession to the ECvHR (see Article 6). ${ }^{59}$ Although the new treaty has not entered into force yet, and even if the effects of the ECvHR would be limited to areas of competence delivered to the EU by the States, ${ }^{60}$ it would have been advisable for the Court to spend some words explaining the legal implications of having ECvHR bindings on EU bodies.

What's more, some cases already occurred where EU acts conflicting with ECtHR law were contested before the Luxembourg Court by Community bodies. We recall here, for instance, how the Parliament maintained, ${ }^{61}$ referring to the alleged illegitimacy of a directive adopted by the European Union Council, that: the "contested provisions do not respect fundamental rights - in particular the right to family life and the right to non-discrimination - as guaranteed by the European Convention for the Protection of Human Rights and Fundamental Freedoms signed in Rome on 4 November 1950 ('the ECHR') and as they result from the constitutional traditions common to the Member States of the European Union, as general principles of Community law; the Union has a duty to respect them

${ }^{59}$ On the Lisbon treaty and fundamental rights protection see P. Passaglia, Il trattato di Lisbona: qualche
passo indietro per andare avanti, 133 FORO ITALIANO 43 (2008); and A. Ruggeri, Ancora in tema di rapporti tra
CEDU e Costituzione: profili teorici e questioni pratiche, available at: www.associazionedeicostituzionalisti.it.

${ }^{60}$ See the statement by the Secretary General Terry Davis, Press release 699/2007 (Strasbourg, October 19, 2007): "I welcome the fact that Article 6 of the new Reform Treaty establishes the legal basis for EU accession to the European Convention on Human Rights. EU accession to this Council of Europe Convention will close an important gap in human rights protection in Europe, and people will no longer be deprived of the right to complain about abuses of their human rights committed in areas in which EU member states have transferred their powers to Brussels. Of course, I can appreciate that this accession can only take place after the Reform Treaty has entered into force, and that it is likely to take some time. In the meantime we will need to resolve several legal, administrative and financial issues. All these arrangements will need to be agreed not only by the EU, but also by the 47 member countries of the Council of Europe. That is why the talks should start immediately."

${ }^{61}$ See C- 540/03 of June 27, 2006, Parliament $v$. Council, dealing with an action of annulment (as pursuant Article 230 TEC) of the last subparagraph of Art 4, para. 1 and 6, and Article 8 of the 2003/86 directive on the right to family reunification. 
pursuant to Article 6(2) EU, to which Article 46(d) EU refers with regard to action of the institutions." 62

Although the ECJ did not find that the challenged norms threatened the exercise of fundamental rights, in particular the right to family life under Article 8 of the $\mathrm{ECvHR}$, it nevertheless maintained that fundamental rights form an integral part of the general law principles the observance of which is ensured by the Court. Moreover, the ECvHR has special significance in that respect, even under Article 6, No. 2, of the TEU, which reads: "the Union shall respect fundamental rights, as guaranteed by the European Convention of Human Rights and, as they result from the constitutional traditions common to the Member States, as general principles of Community law." 63

The reasoning of the Court, surprisingly, does not deal with the potential function of Constitution Article 2 regarding the ECvHR. ${ }^{64}$ Indeed, many authors have supported the idea that the Convention could be given a constitutional nature through the application of Article 2, which makes a generic reference to the fundamental rights' safeguard offered by the Republic of Italy and, according to a widespread interpretation, can include rights that are not explicitly provided in the Constitution. 65

${ }^{62}$ See judgment of June 27, 2006, para. 30.

63 See judgment of June 27, 2006, para. 35, 36 and 37. In particular the Court recalls, inter alia, Case C260/89 ERT [1991] ECR I-2925, paragraph 41; Opinion 2/94 [1996] ECR I-1759, paragraph 33; Case C274/99 P. Connolly v. Commission [2001] ECR I-1611, paragraph 37; Case C-94/00 Roquette Frères [2002] ECR I-9011, paragraph 25; Case C-112/00 Schmidberger [2003] ECR I-5659, paragraph 71; and Case C36/02 Omega [2004] ECR I-9609, paragraph 33. On this point see M. E. Gennusa, La Cedu e l'Unione europea, in I DIRITTI IN AZIONE 91 (M. Cartabia ed., 2007).

${ }^{64}$ See D. Tega, Le sentenze della Corte Costituzionale nn. 348 e 349 del 2007: la Cedu da fonte ordinaria a fonte "sub-costituzionale" del diritto, 28 QUADERni CostiTUtionali 133 (2008); C. Pinelli, Sul trattamento giurisdizionale della Cedu e delle leggi con essa confliggenti, available at: www.associazionedeicostituzionalisti.it; and A. Ruggeri, supra note 49.

${ }^{65}$ Indeed, in decision No. 38 and 159 of 1973 and No. 1150 of 1988, Article 2 of the Constitution is used by the Constitutional Court in order to give constitutional value to some rights recognized in international treaties such as the right to privacy, based on Article 8 and Article 10 of the ECvHR, that are recalled together with Article 2. More clearly, with the decision No. 388 of 1999, the Court affirms that the human rights guaranteed by the ECvHR and by other international conventions find expression and guarantee in the Article 2 of the Constitution; under the general referral to fundamental human rights therein included, moreover, the different formulations used to express them integrate each other, and mutually complete each other in the interpretation, besides the potential coincidence that there could be in two charters on the definition of the same right. On the interpretation of Article 2 as a standard that can give a constitutional value to any right see A. Barbera, Commento all'art. 2, in COMMENTARIO DELLA COSTITUZIONE, 50 (G. Branca ed., 1975). 


\section{E. The Position of International Treaty Law in the Domestic Hierarchy of Legal Sources}

After carefully explaining the reasons why Article 10 and Article 11 cannot serve as a standard of review (more precisely, as an instrument to give the Convention constitutional rank in the Italian system), the Court resorted to the recently amended Article 117, para. 1, of the Constitution, as formerly explained (see part III).

The Protocol's norm, therefore, could not reach a constitutional level, and the Court could use it as a standard of review only if recurring to Article 117, para. 1. At this point, the Court had to specify which rank the Convention (and international treaty law, more generally) could be granted in the domestic legal order.

With regard to placing international treaty law in the domestic hierarchy of legal sources, the Court refers to its own well-established position, reaffirming the peaceful general rule according to which, in the lack of any specific constitutional provision, international norms enter the Italian system with the same rank of the Italian legal act which implements them. ${ }^{66}$ Since the Convention is given force of law through an act of ordinary law in the Italian order, that will be the place in the system of sources occupied by its norms, next to other Italian statute laws: first of all this means that the Convention sets itself below the Constitution. ${ }^{67}$

The platform of Article 117, para. 1, guarantees an "infra-constitutional" rank to international treaty law (ECHR included) in the Italian legal order, and the introduction of this intermediate position - halfway between ordinary law and constitutional law - carries along several technical implications, not to mention systemic problems.

As the Court specifies, an extra source requires a more articulated scheme of inner consistency among the norms: whilst the traditional two-sided constitutionality test is fairly direct (the statute must conform with the Constitution), this three-element relationship requires not only the statute's consistency with the international norm, but also its consistency with the Constitution, although the latter is not a certain outcome.

\footnotetext{
${ }^{66}$ See decision No. 188 of 1980 cited above, where the Court states that it is not possible to conceive a constitutionality question founded on conventional provisions used as standard of review.

${ }^{67}$ See decision No. 349, para. 6.1.1.
} 
Besides, the constitutionality of the international norm must be verified as well, given its position in the hierarchy: the use of Article 117 to "constitutionalise" 68 the international norm versus the statutory act (and, as a result, to challenge its constitutionality) is a legitimate operation only if a preemptive condition is fully met, that is, the international norm must not incorporate any aspect of unconstitutionality. ${ }^{69}$

In other words, since the international norm ends by working as a standard of (constitutional) review, it must implicitly reflect the nature of the higher source which it surrogates: by conforming with the international norm the statute must automatically conform with the Constitution, a three-cornered test is a non-feasible solution, and could lead to confusing results.

This mechanism obviously requires that the international provision does not enter into conflict with any constitutional provision, as there is no room for carving out a "hard core" theory in which a limited set of fundamental constitutional values could nullify the international norm's influence on the domestic order. ${ }^{70}$ In fact, the structure outlined by the Court bears a defined hierarchical aspect: the relationship between charters of rights (such as the Constitution and the European Convention) is played less on an axiological ground (where values could exceptionally prevail) than on a formalistic one (where rules must necessarily apply). ${ }^{71}$

The ordinary judge, therefore, cannot apply traditional criteria to a conflict between the statutory domestic law and the international norm (i.e. the lex posterior and lex specialis principles, that rule the contrast between norms of the same rank). In fact, whilst in the past the judge in such a conflict could behave just as he was handling

\footnotetext{
${ }^{68}$ We use this term to simplify, although the constitutional status is never reached by the interposed international law provision. Besides, the aforementioned mechanism never has the ability to sort this effect, see N. Pignatelli, La dilatazione della tecnica della "interposizione" (e del giudizio costituzionale), 28 QUADERNI COSTITUZIONALI 140 (2008).

${ }^{69}$ On this kind of control, see S. Mirate, Indennità di esproprio e risarcimento da occupazione acquisitiva: la Corte costituzionale inaugura il giudizio di convenzionalità ex art. 117 Cost., 89 RESPONSABILITÀ CIVILE E PREVIDENZA 73 (2008); S. Mirate, GIUSTIZIA AMMINISTRATIVA E CONVENZIONE EUROPEA DEI DirITTI DELL'UOMO. L'ALTRO DIRITTO EUROPEO IN ITALIA, FRANCIA E INGHILTERRA (2007) (published a few weeks before the decisions No. 348 and 349).

70 See part VI below.

71 See A. Ruggeri, supra note 49. See also R. Conti, La Corte costituzionale viaggia verso i diritti CEDU: prima fermata verso Strasburgo, 25 CORRIERE GIURIDICO 206 (2008) ("It seems like the rank of the Convention as a source does not protect the rights of the Convention from those internal domestic regulatory provisions implementing rights set forth under the Constitution.").
} 
two equivalent provisions ${ }^{72}$ (as it actually was the case: a domestic statute vis-à-vis another domestic statute, with the latter implementing the international treaty norm), now the judge cannot compose the clash by his own instruments. It is no more a matter of application of the prevailing norm, but rather a question of constitutionality, and such an issue can be dealt with only by the Constitutional Court.

The Court definitely includes among its prerogatives the task of verifying the constitutionality of international law adhered to by Italy, although admitting in the case at stake that - since the Convention and the Constitution do treat values that sometimes are very similar in a fairly similar way - it is highly unlikely that this test would lead to a decision in which the Court rejects a Convention's norm due to the fact that its conflict with a constitutional provision cannot be resolved.

It is, nevertheless, difficult to understand what the Court refers to when it mentions the possibility of "balancing" the values enshrined in the Convention's provisions with the values granted by the Constitution, in a way that - we can only suppose would lead to a situation where the domestic statute prevails over the international law's provision, as the values enshrined in the former deserve a stronger protection than the values implemented by the latter. ${ }^{73}$ This situation would contravene the "double conformity test" (conventionality and constitutionality) set up by the Court. As a matter of fact, such a test only admits yes/no responses; whereas the balancing moment is not foreseen.

Secondarily, we would like to underline that the "balancing" operation described by the Court could conceal a double nature. As said, the fact that the conventional norm could be overcome by the national ordinary source as a result of the balancing activity is a perspective that undermines the evolutionary momentum that seemed to support these decisions. On the other hand, a balancing comparison can be carried out only between elements of the same nature/rank: therefore it would be implicit in the Court's call for a settling of values that the conventional norm be of the same Constitutional norm's rank. ${ }^{74}$ This ambiguity is likely to depend on the contrast between the opinions of single constitutional judges on the matter at stake.

\footnotetext{
72 Not to mention the risk that the prevalence of the domestic norm on the international one could entail the State's international responsibility.

${ }^{73}$ See A. Ruggeri, supra note 49; and R. Conti, supra note 71, at 214.

74 See V. Sciarabba, Nuovi punti fermi (e questioni aperte) nei rapporti tra fonti e corti nazionali ed internazionali, available at: www.associazionedeicostituzionalisti.it.
} 
Bearing in mind that in the Italian constitutional trial there is no space for concurring or dissenting opinions: the adopted decision must be agreed upon, at least formally, by the whole Court. This requirement could have led to some problems in the formulation of some parts of each one of the decisions under consideration. For instance, it would be difficult to explain why after having set forth the above described precise, and hierarchically inspired, conformity test, the Court somehow disregarded it, and seemed to alter its original intention with some sudden axiological flares such as the call for a balancing moment.

Our view seems to be supported by a comparison between the two sentences. Whilst in decision No. 348, the few lines on the "balancing" clarify that the Court intends to maintain the power to compare the international norm with the domestic norm's content, in decision No. 349 the balancing is mentioned only once, apparently only to explain the creation of the new source's hierarchy (putting the international norm between the ordinary norm and the Constitution represents, in itself, a balancing choice). ${ }^{75}$ In addition, while explaining how this compatibility test works, the No. 349 text talks about the "compatibility of the ECvHR provision ... with the relevant provisions of the Constitution" (emphasis added). This decision seems not to take into consideration the principle repeatedly emphasized by the other decision, that of the necessity for the international norm to conform to the whole set of the provisions of the Constitution.

\section{F. The Decision Avoided by the Constitutional Court: The Disapplication of the Internal Provisions Contrasting the ECvHR. Disapplication versus Direct Application of the International Norm}

As we said above, the fact that the ECvHR lacks a constitutional rank and that no sovereignty limitation can be envisaged impedes the possibility of a disapplication practice by the ordinary judge. The Court condemned the practice of disapplication that some judges had already begun to adopt, when they applied the international norm and, at the same time, made Italian applicable law recede. ${ }^{76}$

Indeed, the Court acknowledged that the Convention is a fundamental charter, as it protects and fosters fundamental human rights and freedoms, but it still consists in

75 See the last words of para. 6.2 of decision No. 349, read "In this way [that is, by checking the ECvHR's conformity with the Constitution] the correct balance is struck." The fact that the two decisions have been written by two different judges could help us appreciate the difference. In particular, a constitutional law professor wrote decision No. 348 (the one calling for the balancing moment), whereas a Community law professor wrote the decision No. 349 (which virtually ignores the aforementioned balancing aspect).

${ }^{76}$ See decision No. 348, para. 3.3. 
a treaty source, that is, it binds the State without having a direct effect in the domestic order: national judges, therefore, cannot apply the Convention in trials before them, disapplying at the same time the internal norms in potential conflict with it. ${ }^{77}$

As said above, the Supreme Court and the Supreme Administrative Court recently, respectively, joined and welcomed the disapplication practice started by some Courts of first instance. ${ }^{78}$ The Constitutional Court, as in regard to these recent trends, took the chance to express its criticism.

This refusal, at first sight, deprives the ordinary judge of its status of "natural judge of the Convention,"79 and determines a material difference with its duties regarding the application of EC law (see below). ${ }^{80}$

In fact, the Court rejects the possibility of the disapplication only, but it does not adopt a clear position on the direct application of the international norm, which is, therefore, allowed. This could mean, in other words, that the ordinary judge is, indeed, entitled to apply the conventional norm directly, ${ }^{81}$ when for instance there

77 See decision No. 348, ibidem.

78 See the recent decision issued by the Court of Pistoia on March 23, 2007: the judge disapplied Article 80, para. 19 of Law 388 of 2000, concerning the immigrant's right to the social allowance, because it conflicted with Article 14 ECvHR. On this point see also Court of Genoa, decision of November 23, 2000; Court of Appeal of Florence decisions No. 570 of 2005 and No. 1403 of 2006, and the Administrative Supreme Court (Consiglio di Stato), I Section, decision No. 1926 of 2002, whereby the Administrative Supreme Court carefully considers the legal ground of the disapplication, reflecting upon the direct effect of the Convention. See also the Court of Appeal of Rome decision of April 11, 2002, in which Article 6, para. 3, let. c), of the ECvHR is applied directly instead of the relevant Italian provision. Even within the Supreme Court's case law different trends could be identified: with the decision No. 28507 of 2005, given on Plenary Session, the Supreme Court recalls the decision No. 10542 of 2002, which synthetically calls for the obligation to disapply the internal provision conflicting with the treaty source bearing direct effect. Besides these decisions, however, the orders of referrals that triggered the constitutionality trial under consideration must be taken into account, where the Supreme Court denies that the ordinary judge can disapply provisions conflicting with the ECvHR.

${ }^{79}$ Acknowledged by the Court in the decision No. 349, para. 6.2.

${ }^{80}$ We must here mention how the Constitutional Court has regularly referred to the disapplication practice described here using the "non application" formula, in order not to stress the unavoidable precedence EC law has on the domestic norm: the mere non application (i.e. the suspension) of the domestic provision sounds less embarrassing than its neat disapplication (which seems to imply a negative judgment on the disapplied norm). See the decision No. 168 of 1991, where the Court expressly talks about the effect of "non application" created by the EC legislation, and advices to avoid the use of the "disapplication" term.

81 See for instance the position of the Supreme Court in its decision of April 5, 2005, No. 7923: "the Convention's provisions impose on the contracting States legal obligations bearing a direct effect" and 
is a vacuum in the domestic regulation. The problem arises, in the Court's view, only when the direct application implies supersession of the relevant Italian norm (i.e., a disapplication).

Accordingly, the judge should behave very differently, depending on whether the international norm insists on a matter already regulated in the domestic order or not. In the first case, he will be forced to refer the question to the Constitutional Court, whilst in the second he will be entitled to apply the international norm in the trial before him.

This material difference could lead to a veritable discriminatory treatment of similar situations, because the decisive criterion as to which procedure must be followed will be, in sum, the potential existence of a domestic regulation concerning the matter at stake. Such a mechanism is likely to sort aleatory outcomes. Moreover, there is the risk of giving the ordinary judge an excess of discretion as to whether, for instance, a domestic norm formulated in a general way is relevant (because it regulates the same situations of the international norm, although more generally) or not (because there is a domestic normative "vacuum" on the particular set of facts regulated by the international norm). ${ }^{82}$

In sum, it looks like the old-fashioned interpretive scheme applies again in this case, or at least echoes in the Court's words: (consistent) interpretation could be allowed even praeter legem, but it cannot be contra legem. The prevalence scheme

"[the Convention's provisions] create rights and duties upon all subjects." For a list of similar decisions by the Supreme Court, see M. Pacini, Verso la disapplicazione delle disposizioni legislative contrarie alla Cedu?, 13 GIORNALE DI DiRITTO AMMINISTRATIVO 389 (2007). In addition, see Commissione Tributaria regionale Lombardia of September 19, 2000, calling for "the direct application of ECvHR's norms by administrative and jurisdictional [State] bodies."

$82 \mathrm{O}$. Pollicino rightly stressed the risk of this discriminatory drift, in occasion of the STALS conference held at the Sant'Anna School of Legal Studies, Pisa, on February 25, 2008. See how this concept is developed in his forthcoming article. O. Pollicino, "The Italian Constitutional Court At the Crossroad Between Constitutional Parochialism and Cooperative Constitutionalism." Case note on judgments no. 348 and 349 of 2007, 4 EUROPEAN CONSTITUTIONAL LAW REVIEW (forthcoming 2008). In particular, he foresees a risk of discrimination due to the different application that ECvHR norms can have, "depending upon whether they apply only to domestic situations (in which case they have an intermediate level between ordinary statutes and constitutional law) or to situations of European law relevance (where, through their qualification as general principles of European law, they have a constitutional status)." See for instance the decision of the Supreme Court (Criminal Section) dated February 6, 2003, where the Supreme Court, after stating that EC law has a direct effect which supersedes conflicting domestic law, apparently skips a middle step and directly ends up by saying that "the norm under Article 2, No. 2, of the Convention ... could not but find direct application." It seems that the Court here implicitly considers the conventional norm as forming part of the EC law. Contra, see Supreme Court, Criminal III Section, decision No. 254 of January 12, 1999, where Article 5, No. 5 of the Convention was deemed to serve as a general guideline, and not to have a directly applicable content. 
discolours and turns into a merely interpretive guideline whose criteria are more then well-known, and definitely not that revolutionary.

It is important to keep record of ordinary judges' reactions following the decisions commented, so as not to run the risk of losing touch with the facts. In this view, it is important to note how the Court of Appeal of Florence, which in the past joined the crew of the "disapplying" judges, has recently conformed to the new directive issued by the Constitutional Court, lodging a constitutionality question in a case where disapplication could intervene as well. ${ }^{83}$

\section{G. Bundesverfassungsgericht and the CoE System: The Counter-Limits Theory in the October 14, 2004 Order. Some Remarks on the Consistent Interpretation by the Judge}

As we stated above, the need for a constitutionality test on the Convention norm excludes the possibility of having a limited set of fundamental rights that could serve as a counter-limit; indeed, every norm of the Constitution shall be respected by the international norm challenged.

Some of the referring judges, in fact, had offered the Court an alternative solution to the declaration of unconstitutionality of the domestic norm based on the counterlimits mechanism. In this respect we quote an excerpt of the order of referral No. 401 of the Supreme Court dated May 20, 2006, that states as follows:

[T] he direct effect in our legal order of legislative, administrative and judicial power of Community bodies is not such as to modify the constitutional structure of our legal system. Some counter-limits to potential sovereignty limitations follow this constitutional structure: the Constitutional Court has identified, among others, the inalienable human rights, and the fundamental principles of our constitutional system. Therefore, it could be maintained, in the light of the case-law of the Constitutional Court (and also of the case-law of

${ }^{83}$ As for expropriation for public purposes, see order No. 616 of 2007 of the Court of Appeal of Venice and order No. 780 of 2007 of the Court of Appeal of Florence. As for unlawful expropriation, see order No. 712 of 2007 of the Court of Appeal of Naples, recently handed down by the Constitutional Court with the decision No. 66 of 2008, in which the Court, referring to the decision No. 349/2007, returned the constitutional question to the judge. All these orders are based on the violation of the cited Article 117, para. 1. 
the ECtHR), that the equalization of the compensation for expropriation to the market value of the land does not take into account the constitutional principle stating that property right withdraws, when faced to the primary value of the public interest. ${ }^{84}$

The parallel between the communitarian order and the CoE system is clearly sketched up here with the intention of legitimizing the potential use of the counterlimits by the Constitutional judge. In this scenario the social function of property, as pursuant to Article 42 of the Constitution, could be envisaged as a constitutionally indispensable principle, and could work as a limit to the adaptation of the domestic order to the rules of the ECvHR and to their interpretation given by the Strasbourg Court.

This interpretation is not something absolutely original in the European framework, ${ }^{85}$ indeed the Bundesverfassungsgericht (BVerfG - German Federal Constitutional Court) had already proposed it in the order dated October 14, 2004. That decision, voted by unanimity, applied the well-known counter-limits theory as developed in the Solange case-law - to the relationship between the German Constitution and the European Convention (and, more generally, international law).

The first part of the decision, in which the ECvHR is equalized to any other statutory norm, gave rise to a diverse wave of criticism. In fact, the BVerfG firstly assesses that in the German legal order the Convention, since it is given force by an ordinary federal statute, gets the same rank as the ordinary ratification norm. Therefore, ordinary judges are subject to the Convention, as pursuant to Article 20 of the Constitution, just as they are to any other statutory norm: conventional rules cannot serve as the standard of review in a constitutionality trial. ${ }^{86}$

The German Court, nevertheless, acknowledges the existence of an obligation bearing upon judges, i.e. the consistent interpretation of domestic law to international and supranational law. However, this is not an absolute obligation,

${ }^{84}$ See Supreme Court, order May 20, 2006, No. 402, for a similar reasoning.

${ }^{85}$ For a comparative overview on this issue, see L. MONTANARI, I DIRITTI DELL'UOMO NELL'AREA EUROPEA TRA FONTI INTERNAZIONALI E FONTI INTERNE (2002); L. Montanari, La difficile definizione dei rapporti con la CEDU alla luce del nuovo art. 117, un confronto con Francia e Regno Unito, 10 DIR. PUB. COMP. EU. 204 (2008).

86 See F. Müller and T. Richter, Report on the Bundesverfassungsgericht's (Federal Constitutional Court) Jurisprudence in 2005/2006, 9 GERMAN LAW JOURNAL 164 (2008). 
since its performance is necessary only when the effort is methodically sustainable (methodisch vertretbar): in particular the BVerfG affirms that "this classification means that German Courts must observe and apply the Convention within the limits of methodically justifiable interpretation like other statute law of the Federal Government." 87 When it is not the case (that is, when no consistent interpretation can be provided), the judge must declare the reasons why he did not conform to the domestic norm, and these reasons will be subject to the BVerfG's exam. The latter can be consulted through an individual or incidental appeal, and plays the role of the "transmission chain connecting international and constitutional laws, and of the gatekeeper of Constitution's primacy." 88

Even though this picture does not seem to reveal a high degree of openness to international sources of law, including the European Convention, the order issued by the German Federal Constitutional Court is nevertheless of much interest, as it formulates the obligation of consistent interpretation, and the effects in the domestic order this obligation may imply.

When no "adapting" interpretation is possible, there is an unsolvable conflict between the domestic source and the conventional one. Such a conflict occurs when the statutory norm, as interpreted in the light of the ECvHR, counters the substance of a fundamental constitutional right: the statutory domestic norm - as construed following the Constitution's directions - must then prevail on the international obligation.

As in regard to this point we should mention the core theory put forward in the text of the decision: the Court borrows from its well-established case-law the counterlimits instrument, transplants it in the Constitution - ECvHR dialogue and limits its efficacy to a particular set of matters. Counter-limits vis-à-vis the Convention, indeed, can function in a few occasions only, and the Court takes the effort to list

${ }^{87}$ See para. 32 of the decision.

88 See. F. Palermo, Il Tribunale federale e la teoria selettiva del controlimiti, 25 QUAD. COST. 181 (2005). More specifically, if the judge does not take the ECvHR and its interpretation into account, a Verfassungbeschwerde can be lodged, challenging the domestic norm for violating the relevant fundamental right as set forth in the Constitution together with Article 20, para. 3. For a detailed analysis of the decision under consideration, see also A. Di Martino, L'efficacia delle decisioni della Corte europea dei diritti dell'uomo nel diritto tedesco: il significato del Görgülu-Beschlu $\beta$ per un tutela multilivello dei diritti, 8 DIR. PUB. COMP. EU. 911 (2006); A. Di Martino, L'efficacia delle sentenze della Corte EDU nel diritto interno: proposta per una soluzione interpretativa del contrasto tra giudicati alla luce di una pronuncia del Bundesverfassungsgericht, in ALL'INCROCIO TRA COSTITUZIONE E CEDU 99 (R. Bin, G. Brunelli, A. Pugiotto, P. Veronesi eds., 2007). 
them: family law, foreigner law, and personality law. ${ }^{89}$ These fields, in the Court's words, share a common feature because they "serve as indicators of the constitutional identity of the State."

Even if it is true, as many authors have stated, that these sectors are likely to expand almost uncontrollably upon other legal fields, we still have to appreciate the effort the German Court has made to limit the domestic law primacy to a few sectors, where a delicate balancing between constitutionally granted values has to intervene. This choice would logically imply that in any other sector of law the conventional norm, as interpreted by the ECtHR, prevails. ${ }^{90}$

For these reasons, this decision could be the result of a veritable step forward towards a better coordination between orders, i.e. the (judicial) codification of a cooperation relationship between the National constitutional judge and the European judge. Indeed, the Court protects the margin of discretion ordinary judges must enjoy when autonomously deciding a case, invites them to conform their rulings to the European case-law, and, at the same time, takes the charge of monitoring the application of the constitutional principle of Völkerrechtsfreundlichkeit, according to which domestic law must be interpreted so as to avoid the conflict with international law..$^{91}$

In the Italian legal order, the "constitutional resistance" to the influence of international law is not of a substantive (i.e. based on values) nature, but of a mechanical and hierarchical kind, thus, the obligation upon the judges to choose where possible - the consistent interpretation bears a different meaning in the two systems.

In Germany, national law is subject to two opposite pressures when confronted with the Convention: on one hand, consistent interpretation "stresses" the limits of national law to achieve a possible conciliation between the sources; on the other hand the "hard core principles" reassess the pre-eminence of the domestic order in

89 As for the personality law, it is worth remembering the decision of the ECtHR of June 24, 2004, Hannover v. Germany, case No. 59320/00, in which the ECtHR's interpretation of the extent of the right to privacy is different from the interpretation given by the BVerfG in a decision on the same case only a few months before.

${ }^{90}$ See. F. Palermo, supra note 88 , at 184.

${ }^{11}$ See. L. Violini, L'indipendenza del giudice e il rispetto del diritto internazionale secondo una recente decisione del BVerfG: bilanciamento o prevalenza dei principi costituzionali nazionali?, 7 DIR. PUB. COMP. EUR. 1014 (2005). 
those areas where no cession of sovereignty to the international organizations has occurred, and intervenes in, presumably, exceptional cases.

On the contrary, the pre-requisite of consistent interpretation in the Italian system ${ }^{92}$ seems to represent a useless exercise when it manages to achieve consistency of the Italian norm solely with the Convention. Indeed, the constitutionality test on the international norm is not occasional as it is in Germany, and must be carried out even when the "saving" interpretation of the judge has healed the relationship between the statutory norm and the international one. ${ }^{93}$ In other words, the judge should better check the constitutionality of the international norm before verifying the conventionality of the domestic norm; two tests should be done, and two distinct obligations of consistent interpretations bear on the judge. ${ }^{94}$

Nevertheless, we would like to welcome the introduction in our system of an obligation, upon the ordinary judge, to conform his interpretation to the norms of international law. ${ }^{95}$ An analogue rationale can be found in the "Charming Betsy doctrine" formulated by the Supreme Court of the United States, according to which "An act of Congress ought never to be construed to violate the law of nations if any other possible construction remains." 96

${ }_{92}$ The technique of the consistent interpretation is a technique which the ordinary judge is obliged to apply before lodging a challenge of constitutionality before the Constitutional Court: before asking the Court's intervention, indeed, the judge must try to find an interpretation according to which no conflict between the statutory norm and the Constitution can be envisaged. In fact, there has been occasions where the duty to interpret the provision consistently with the Constitution was absolutely tied with the duty to carry out a Convention-consistent interpretation, see for instance decision No. 413 of 2004, where the Court states: "the Constitution-consistent interpretation is strengthened by some important norms, even of supra-national nature. [...] The ECvHR [...] provides the right for a just compensation for illegal detention, without any exception." See on this point B. Randazzo, La Convenzione Europea dei Diritti dell'Uomo nella giurisprudenza costituzionale, available at: www.cortecostituzionale.it, September 2007; B. Randazzo, Costituzione e Cedu: il giudice delle leggi apre una «finestra» su Strasburgo, 14 GIORNALE DI DIRITTO AMMINISTRATIVO 25 (2008).

${ }^{93}$ We owe this sharp argument to N. Pignatelli, supra note 68.

${ }^{94}$ Not to mention the obligation to choose an interpretation of domestic norms that is consistent with EC law, see Advocate General Saggio's Conclusions on joined cases from C-240 to C-244/98, Océano Grupo Editorial.

95 This obligation was somehow implicit in some previous decisions of the Supreme Court, see for instances the set of decisions in which the Supreme Court reads Article 143 of the Criminal Procedure Code in the light of Article 6, par. 3, let. (a) of the Convention, thereby acknowledging the right of people charged with a criminal offence to be informed of their charges in a language they understand (see, among others, decisions December 23, 1987; December 18, 1992; April 26, 1999 and October 14, 1999).

${ }^{96}$ See Murray v. The Charming Betsy, 6 U.S. 2 Cranch 64 (1804). 
The principle enshrined in such a doctrine (and in the similar obligation the Constitutional Court imposes on Italian judges) is obviously a strong incentive to the harmonization of concurring case laws of different judicial bodies as regards similar issues; it goes without saying that in the field of human rights, where the sometimes overlapping jurisdictions of a number of tribunals seem to lack an effective normative coordination between themselves, such a judicial effort to preserve homogeneity is more than opportune.

It is, nevertheless, curious how the forced coexistence of two rationales for the new reasoning (the formalistic and the axiological one, seen above) ends up creating a paradoxical situation in which the Convention must be interpreted consistently with the Constitution (as said, because of the need for constitutional control), whilst the Constitution itself, in its turn, must be interpreted consistently with the Convention. ${ }^{97}$ This uneasy result, once again, was obtained by mixing the traditional hermeneutic function of the Convention with its new subordinated position in the domestic legal order.

\section{H. The Importance of the Strasbourg Court's Case-Law in the Italian Legal System}

We would like to focus our analysis on another aspect of the Court's reasoning that we have deliberately overlooked so far: the attention showed by the Court towards the Strasbourg Court's case law..$^{98}$

97 See par. 6.1 .1 of the 349 decision, which reads: "The interpretive role of the ECvHR has been acknowledged, with respect both to constitutional review standards and to challenged provisions (see decision No. 505 of 1995 and order No. 305 of 2001)." On the interpretation consistent with Constitution and the integration between legal orders, see A. Guazzarotti and A. Cossiri, La CEDU nell'ordinamento italiano: la Corte costituzionale fissa le regole, available at: www.forumcostituzionale.it, 2008.

98 As regards the importance of the single decisions of the Strasbourg Court, see for instance the 1226 Resolution of the Council of Europe Parliamentary Assembly, dated September 2000. In a passage of the text, it is stated that: "At national level: legislators should ensure that new legislation fully complies with the Convention; governments should take the necessary action to execute the Court's judgments in order to avoid any recurrence of violations; governments should remedy the applicant's individual situation and, where necessary, they should ensure that their legislation provides for the revision of a trial following a judgment of the Court; judges and administrators should work towards giving direct effect to the Court's judgments so that national court authorities can directly apply them; national authorities should make sure that the Court's case-law is adequately circulated in the language(s) of the country; until definitive reforms come into effect, domestic authorities and courts should adopt interim measures." It is not the case that the parties of the trial before the referring judge stressed the importance of this resolution, and included it in the brief to the Constitutional Court. 
Indeed, the Constitutional Court regularly refers to the norms of the European Convention "as interpreted by the ECtHR." This is a clear example of how the Court intentionally neglects a positivistic approach to international law, and adopts instead a dynamic understanding of the Convention: the standard of review for challenging the constitutionality of an Italian act is not the norm of the Convention in itself, but the norm as construed by the judicial body charged with its interpretation and adjudication.

It is worthy here to quote an excerpt of the No. 348 decision:

Since legal norms live in the interpretation that legal professionals give to them, in particular judges, the obvious consequence of Article 32, paragraph 1, of the European Convention is that among the international obligations Italy entered into by executing and ratifying the ECvHR there is the obligation to adapt its domestic legislation to the provisions of this treaty, as interpreted by the [European] Court, which has been introduced specifically to perform their interpretation and application..$^{99}$

The Constitutional Court underlines this meeting of interests, when it states that its role is different from the role of the Strasbourg Court, but that their common purpose is to protect fundamental human rights to the best extent possible. This referral to the best protection seems to imply the willingness to sacrifice, if it is the case, the domestic solution when the solution offered or supported in Strasbourg seems to achieve better results.

Whereas this broadminded reading of the international norm (which does not consist in the mere provision codifying it) is certainly opportune when dealing with the CoE system, it could give rise to some doubts if applied to other international law orders. We should bear in mind, in fact, that the Court takes avail of this double-decision and of the ECvHR example to specify the role of any international treaty norm in the Italian order.

Accordingly, the reasoning the Court used with the Convention should work with provisions of other international law systems as well, which could lack an organ of "central" adjudication, a body to whom the Court could address to verify the

${ }^{99}$ See decision No. 348, para. 4.6. 
official and authentic interpretation of the norm at stake. Let's not forget that the international law system, traditionally, foresees a situation where States bind themselves to the terms of an agreed treaty and, unless otherwise specified in its text, they severally play as official interpreters of such a set of norms. ${ }^{100}$ More generally, not every treaty provides for a monitoring or judicial body, thus, it could often be difficult for the Court to spot the "official" interpretation of an international law provision. ${ }^{101}$

Apart from the problem concerning international legal orders deprived of an "authoritative interpreter," the extension of the model drawn by the Court with regard to the ECvHR system to other international treaties could arouse another main cause of concern. In the Italian constitutional order, the Government is enabled to conclude international agreements in a simplified way (accordi in forma semplificata), therefore there is no need for further ratification by the Parliament if the parties to the treaty have agreed that the States are bound upon the sole signature of the treaty, as pursuant to Article 12 of the Vienna Convention on the Law of Treaties.

We would, then, have a situation where a source adopted without the control of the Parliament (the international simplified agreement) would supersede a domestic norm of ordinary rank. There is no need to add any further consideration to understand how unfeasible this solution is. We think that this evident problem could be prevented if we carefully examine the content of Article 117, paragraph 1, of the Constitution, and we agree with those scholars ${ }^{102}$ who maintain that international, simplified agreements do not fall within the scope of application of the constitutional provision due to their lack of democratic justification.

\footnotetext{
100 This is the case, for instance, of the United Nations Charter.

101 This question is likely to surface with regard to the ILO Convention. Indeed the labour judge of the Tribunal of Brescia has lodged a constitutionality question (order of January 15, 2007) in which he challenges the constitutionality of some Italian statutory provisions, referring to Article 117, paragraph 1, of the Constitution, for violating the No. 97 of 1949 and the No. 143 of 1975 ILO Conventions. The question is now pending. We must recall that the ILO Conventions had already been invoked in connection with Article 10 and Article 117, para. 1, of the Constitution (in particular both the ILO Conventions No. 97/1949 and No. 158/1981) in front of the Italian Constitutional Court. However, The Court, in the decision No. 324/2006, considered the question inadmissible because the judge would have been able to resolve the question by interpreting the norm consistently with the Constitution.
}

102 See L. Bartolomei, La garanzia costituzionale dei trattati alla luce della legge 5 giugno 2003, n. 231 contenente disposizioni per l'adeguamento alla legge costituzionale 18 ottobre 2001, XX Rivista di diritto internazionale privato e processuale 853 (2003); P. Cavaleri, Articolo 1, in L'ATTUAZIONE DEL NUOVO TITOLO V, COMMENTO ALLA LEGGE “LA LOGGIA” 6 (P. Cavaleri and E. Lamarque eds., 2003). 
Indeed, L. Elia, former president of the Constitutional Court, when asked by the Parliament to illustrate the meaning of the amended Article 117, paragraph 1, mentioned the possibility that, due to the increased influence all treaties could have, the Parliament could be called to exercise a more rigid control over the Government's external action, "and to be more alert and demanding when conceding the Government the authorization to ratify a treaty, following the example of Senate of the United States."103

\section{Degree of Protection and Lack of Protection of a Right: Hypotheses Conflict Between the Italian Framework of Safeguard of Fundamental Rights and the Council of Europe System}

As for the possible conflicts that are more likely to occur between the Italian framework of the safeguard of fundamental rights and the CoE system, we can conceive a case of difference on the degree of protection of one right granted by the two systems, as it was been in the case under consideration. ${ }^{104}$ In similar cases, a settlement could be most likely to originate from an interpretive effort, as the Italian Constitutional Court itself recognized, when it affirmed that: "from the jurisprudential trend held by this Court in the past it is possible to infer - in principle - an acknowledgment of the particular relevance of the Convention's provisions, due to its content. This relevance requires an effort, especially on the interpretative level, to grant a basic sameness and integration between the guarantees set by the European Convention of Human Rights and by the Constitution, that the legislator must respect and execute." 105

In this sense, it is easier to understand why the Court intended to introduce the need for a "balancing moment" in its review of conventional law: the mere compatibility with the Constitution is often obvious, as both charters are designed to protect the same rights. As for the intensity of the protection, instead, the Court could intervene and disregard the higher standard set by the ECtHR, claiming that the need for protecting another concurring constitutional right had forced the Court to choose a compromise, partially sacrificing both rights. This is the option that the Court could have preferred in deciding the No. 348 and 349 cases, if it had held that the social function of property right bore such a material relevance that it justified

${ }^{103}$ See the report of the Senate session dated March 8, 2001. On this point see also, F. Ghera, Una svolta storica nei rapporti del diritto interno con il diritto internazionale pattizio (ma non con quelli con il diritto comunitario), 133 FORO ITALIANO 52 (2008).

${ }^{104}$ See for instance the conception of privacy that the ECtHR uses in the Hannover v. Germany case, cited above, and how it differs from the same concept developed by the German Constitutional Court.

${ }^{105}$ See decision No. 349, para. 6.1.2. 
the otherwise unlawful violation of property right as represented by a partial compensation.

However, is it possible that a conflict could be envisaged not solely in connection with the degree of protection, but also with the lack of protection of a fundamental right. An example is represented by the decision Dorigo $v$. Italy, in which the European Commission of Human Rights condemned Italy for violation of Article 6, para. 3, let. d), of the ECvHR, because the criminal trial did not respect the right of the defendant "to examine or have examined witnesses against him and to obtain the attendance and examination of witnesses on his behalf under the same conditions as witnesses against him," a right needed to ensure due process conditions. ${ }^{106}$

In particular, Article 630, let. a), of the Italian criminal procedure code provides an exhaustive list of the cases that can legitimate a party to ask for the review of a sentence having obtained the force of res judicata, but the list does not include the conflict between the final sentence and a decision of the ECtHR on the same facts.

The decision of the European Commission, however, could not entitle the summoned judge to review the national decision, because Article 630 list is complete, and cannot be integrated. Therefore, the judge lodged a question of constitutionality before the Constitutional Court, challenging the constitutionality of that provision under Article 3, 10, para.1, and 27 of the Italian Constitution. In fact, he did not use the Article 117, paragraph 1 to invoke the violation of Article 6 of the ECvHR but he proposed, in the referral, the direct application of Article 46 of the Convention (which sanctions the effectiveness of the decisions of the Strasbourg Court) and the review of the process, as a consequence of the direct application of Article 6.107

The Supreme Court, in the meantime, had already shown some relevant signs of openness to the ECvHR system, also bearing in mind the continuous solicitations by the Committee of Ministers of the Council of Europe, which since 1999 had been asking Italy to adopt the necessary measures to reopen any trial ended with an unfair condemnation. ${ }^{108}$

\footnotetext{
${ }^{106}$ See Commission, Dorigo v. Italy, September 9, 1998. In particular, Mr. Dorigo was condemned on the basis of some witnesses' declarations that were not confirmed during the judicial debate.

107 See Court of Appeal, Bologna, order No. 337 of March 15, 2006 (Dorigo case).

108 See on this point A. Guazzarotti, Il caso Dorigo: una piccola rivoluzione nei rapporti tra CEDU $e$ ordinamento interno?, 25 QUESTIONE GIUSTIZIA 149 (2007); R. Conti, La Corte dei diritti dell'uomo e la Convenzione europea prevalgono sul giudicato - e sul diritto - nazionale, 24 CORRIERE GIURIDICO 689 (2007).
} 
In the Somogy case, 109 indeed, the Supreme Court decided to re-open the process, in accordance with the ECtHR's ruling, ${ }^{110}$ by using the mechanism of the reopening of terms (restituzione nel termine) in the case of a process celebrated in absentia. ${ }^{111}$ Also, in regard to the incarceration of Mr. Dorigo, the Supreme Court had already stated that the judge of the execution must declare the impracticability of the incarceration under Article 670 of the Criminal Procedure Code, ${ }^{112}$ once that was accomplished that the ECtHR found that the condemnation was inflicted in violation of Article 6 of the ECvHR. ${ }^{113}$

Therefore, the Supreme Court tried to find an internal instrument to reopen a process celebrated in violation of the $\mathrm{ECvHR}$, with an operation that seems to be halfway between the direct application of the cited Article 6 of the Convention and the consistent interpretation of Article 670 of the Criminal Procedure Code with the ECvHR norm, as resulting from the jurisprudence of the Court of Strasbourg.

For the sake of completeness, we mention here the Cat Berro case (even though it concerns the issue of reopening a trial - concluded with a condemnation in default of appearance - that the ECtHR had declared in violation of Article 6, rather that the right to examine witnesses). Here the Supreme Court disregarded the rationale of the quasi-contemporaneous Dorigo case, stating that the solution to redress the conflict with the European charter is not to be found under Article 670 of the Criminal Procedure Code, but in the application of the reopening of terms (under Article 175 of the Criminal Procedure Code, as in the Somogy case). ${ }^{114}$

Recently, with order No. 129/2008,115 the Court issued its decision on the Dorigo case adopting an order whereby it rejected the question of constitutionality as

\footnotetext{
109 See Supreme Court, I Criminal Section, July 12 - October 3, 2006, No. 32678.

110 See ECtHR, Somogy v. Italy, No. 67972/01.

${ }^{111}$ See Art 175 of the Italian criminal procedure Code, which in the meanwhile had been amended by the legislator.

112 Which regulates the mechanism of the incarceration's suspension (sospensione dell'esecuzione).

${ }^{113}$ See Supreme Court, I Criminal Section, decision January 5, 2007, No. 2800.

114 On the mechanisms used by the Supreme Court in Somogy, Dorigo and Cat Berro case to reopen the process and the possible internal solutions, see A. Pugiotto, Vent'anni dopo l'insegnamento di Giovanni Battaglini, in ALL'INCROCIO 191 (R. Bin, G. Brunelli, A. Pugiotto, P. Veronesi eds., 2007); and A. Filippini, Il caso Dorigo, La CEDU e la Corte costituzionale: l'effettività della tutela dei diritti dopo le sentenze 348 e 349 del 2007, available at: www.costituzionalismo.it.

${ }^{115}$ Dated April, 30, 2008.
} 
groundless, as regarding the standards invoked (Article 3, 10, para. 1, and 27 of the Italian Constitution, Article 117, para. 1 was not proposed). The Court, thereby, confirmed the view adopted in the No. 348 and 349 decisions, and refused the possibility of invoking the European Convention by using Article 10 of the Constitution. ${ }^{116}$

The Court argued that it could not integrate the list of Article 630 by means of declaration of unconstitutionality; such integration, in fact, would amount to a law making activity that the Court is not entitled to perform. It would be up to the legislator, instead, to fine-tune the relevant regulation, and to provide for the most opportune modalities of reopening of the trial. ${ }^{117}$ In any event, this decision allowed the Court to address an urgent request (pressante invito) to the legislator, to amend as soon as possible the domestic provisions in accordance with the directions of the jurisprudence by the Court of Strasbourg. ${ }^{118}$

It is worthy to note how the Court decided to confirm its views in the No. 39 decision of 2008, dated February 27, 2008, as well. It declared the unconstitutionality of two provisions of the Italian Former Bankruptcy Law ${ }^{119}$ of 1942 under two standards of review: Article 3 and Article 117, paragraph 1, of the Constitution, as integrated by Article 8, paragraph 2, of the ECvHR, in the interpretation given in its recent decisions by the Strasbourg Court. ${ }^{120}$

In this case, it is interesting to point out, how the Court craved rehearsing the reasoning of the No. 348 and 349 decisions, with the vision to strengthen and reaffirm its value, in particular as concerns ECtHR's case-law, "whereby Member States are bound to abide, except for the constitutionality test." 121 The Italian Court referred back to some decisions of the Strasbourg Court, with an eye to define the

116 See $\S 4.2$ of the Dorigo decision.

117 On this, see A. Cisterna, La rimozione della detenzione iniqua è l'unico rimedio congruo e praticabile, 15 (Issue 20) GUIDA AL DIRITTO 67 2008); V. Sciarabba, Il problema dell'intangibilità del giudicato tra Corte di Strasburgo, giudici comuni, Corte costituzionale e... legislatore?, available at: www.forumcostituzionale.it.

118 This request represents an example of a typical species of decision that the Court can adopt, classified by the Italian scholarship with the expression of 'warning decisions' (sentenze monito). On this classification see E. Malfatti, S. Panizza, R. Romboli, GIUSTIZIA COSTITUZIONALE 141 (2003); R. Romboli, Il giudizio di costituzionalità delle leggi in via incidentale, in AGGIORNAMENTI IN TEMA DI PROCESSO COSTITUZIONALE (2002-2004) 127 (R. Romboli ed., 2005).

${ }^{119}$ Namely Article 50 and 142 of the Royal Decree No. 267 of 1942, in the text preceding the 2006 reform.

${ }^{120}$ In particular, see Vitiello v. Italia, No. 77962/01.

${ }^{121}$ See $\S 5$ of the decision. 
wide notion of "private life" as referred to in Article 8 of the Convention, that "does not exclude, in principle, professional or business activities, given that in the business environment, indeed, people establish numerous relations with the external sphere," and that leads the Constitutional Court to declare the unconstitutionality of the challenged provision. ${ }^{122}$

\section{J. The Historical Perspective of the Decisions Under Consideration: The Parallel With the EC Legal Order}

In conclusion, we deem it necessary to draw a parallel between the content of the decisions commented on and the process that took place in the 1960s and in the 1970s in regard to the EC law. Indeed, when the debate about the role of EC law in the Italian legal order arose, the Constitutional Court took a position that was quite similar to its current one regarding international treaty law, and explained its view in the very same terms used in the No. 348 and 349 decisions. ${ }^{123}$

In its decision No. 232 of 1975 the Court excluded "disapplication as the result of the possibility, left to the Italian judge, to choose between the EC norm and the domestic norm on the basis of a discretionary evaluation of their respective force." In another passage of the same decision, the Court stated that "the judge, when facing the situation following the adoption of Italian norms implementing Community regulations bearing a direct effect, must pledge the question of their constitutionality."

\footnotetext{
${ }^{122}$ According to some authors, in this decision the Constitutional Court seems to enlarge its mandate to monitor the consistency between national law and international obligations, asserting its right to intervene even to rule the conflict between international law and a previous domestic statutory norm (rectius: a domestic norm adopted prior to the domestic law implementing the international norm). In these cases, indeed, it would go without saying, under the lex posterior principle, that the domestic norm would be implicitly invalidated, without the need for a constitutionality test. Others maintain that the vague wording of Article 8 of the Convention could not trigger a strict lex posterior mechanism; hence this decision rather reflects the decisive importance lying in the Strasbourg case-law. For an extensive analysis of this issue, see V. Sciarabba, Il problema dei rapporti tra (leggi di esecuzione di) vincoli internazionali e leggi precedenti nel quadro della recente giurisprudenza costituzionale (a margine della sentenza della Corte costituzionale n. 39 del 2008), available at: www.forumcostituzionale.it; R. Mastroianni, La sentenza della Corte cost. n. 39 del 2008 in tema di rapporti tra leggi ordinarie e CEDU: anche le leggi cronologicamente precedenti vanno rimosse dalla Corte costituzionale?, available at: www.forumcostituzionale.it (the Author rightly notes that this position adopted by the Constitutional Court will probably lead to an increase of its workload).

${ }^{123}$ For a careful description of the dynamics between national, constitutional and conventional law, see R. Cafari Panico and L. Tomasi, Il futuro della CEDU tra giurisprudenza costituzionale e diritto dell'Unione, 10 DIR. PUB. COMP. EU. 186 (2008).
} 
It is very easy to recognize in this thought pattern the same reasoning of the 2007 decisions. Whilst it was fully understandable that the Italian constitutional order had to open to the entry of EC law gradually, back when the EC order was dawning, it is less reasonable to adopt this very cautious approach now. The system set forth by the Council of Europe, has existed for half a century, and its action is surrounded by a general consensus that clashes with the meticulous control test built by the Constitutional Court. The field of human rights, moreover, is probably the only one where States can limit (integrate?) their own sovereign power entrusting competences to a supra-national body without fear of having their authoritativeness, or their State identity, decreased. ${ }^{124}$

This to say that these decisions, besides being mostly motivated under the technical aspect, look a little old fashioned, like echoing the starting chapter of a story for which we already know the epilogue.

As we know, the European Court of Justice ${ }^{125}$ set the ultimate standard regarding the direct effect of EC law and its supremacy over conflicting national law, and the Constitutional Court could not but accept this interpretation, and reaffirm it in Decision No. 170 of $1984 .{ }^{126}$ After that, there was no doubt that the ordinary judge was not only entitled, but even requested to disapply the internal conflicting provisions, and to give application to the relevant EC norm.

After 1984, the ordinary judge was to some extent compensated for the forced deprivation of part of its discretionary power (consequent to the automatic prevalence of community law on domestic law), with a new competence; the judged cannot choose which law to apply (EC law must always be preferred), but at least he bears the power to disapply the internal source and to apply the EC norm. On the contrary, the ordinary judge that identifies a conflict between the Italian norm and the Convention, and that verifies that no possible consistent interpretation could be found, has no alternative but to lodge the constitutionality question to the Constitutional Court; the (apparently) unconditional prevalence of the international norm on the statutory source cannot be handled by the ordinary

\footnotetext{
${ }^{124}$ See decision No. 388 of 1999: "Besides the sameness [of human rights provisions] in the charters that regulate their protection, the different formulations implementing them can integrate between themselves, and complete each other in at the interpretation stage."

125 See case 35/76, Simmenthal SpA v. Italian Minister for Finance [1976] ECR 1871; [1977] 2 CMLR 1.

126 See Granital v. Italian Minister for Finance, No. 170/84, June 8, 1984.
} 
judge, whose role is only to refer to the Constitutional Court. 127 To prevent this drain of competence the judge could be tempted to abuse the consistent interpretation, so as to avoid referring the case to the Constitutional Court. ${ }^{128}$

In particular, it is manifest that the very same peculiarity that induces the Court to acknowledge the monopoly of interpretation of ECvHR upon the ECtHR, in its role of authentic interpreter, is the same one that led the Court in the past to acknowledge the possibility, regarding the EC law, of the direct disapplication of the domestic conflicting norm. Indeed, the role of an authentic interpreter played by the European Court of Justice correctly ended up causing the exclusion of the constitutional control on EC law, whereas in the No. 348 and 349 decisions the acknowledgment of the binding force of the ECtHR's case law is still accompanied by the need for the Constitutional Court's interpretive interference. ${ }^{129}$

Apart from the abovementioned considerations on the opportunity of the constitutional control exercised by the Court on the Convention, we just mention here to risk, perceived also as in regard to other European jurisdictions, that the Italian Constitutional Court, once subject both to the EC primacy and the international treaty law precedence, would end up by having its competence shrunk to the "internal side" of the Italian normative production, that is, the Court would be de facto declassed to the rank of "regional" court. ${ }^{130}$ It is worthy here to recall the sharp conclusion of M. Cartabia, who notes how "the outcome of this double trend [that of enlarging the competence of the central European Tribunals, while at the same time entrusting ordinary judges with new tasks], that fosters at once centralisation and spreading, could be the marginalization of the Constitutional Court."131

\footnotetext{
127 See M. Luciani, Alcuni interrogativi sul nuovo corso della giurisprudenza costituzionale in ordine ai rapporti fra diritto italiano e diritto internazionale, 25 CORRIERE GIURIDICO 204 (2008); R. Conti, supre note 71, at 213 (underlining the lack of a mechanism like Article 234 TCE in the ECHR system).

${ }^{128}$ For a careful evaluation of the role of the ordinary judge according to the instructions of the decisions commented here, see A. Bultrini, Le sentenze 348 e 349/2007 della Corte costituzionale: l'inizio di una svolta?, XXV Dir. PUB. COMP. EU. 171 (2008).

129 See the decision No. 10 of 1993, then disregarded by the subsequent case law, which tried to concede Italian norms implementing the ECvHR an atypical force, higher than the ordinary force of statutory law.

${ }^{130}$ As sharply argued by M. Luciani, supra note 127, at 205.

131 M. Cartabia, La Costituzione italiana e l'universalità dei diritti umani, available at: http://www.astridonline.it/rassegna/30-04-2008/Cartabia_-Lincei_-10_1_2008---def.pdf, 8 .
} 
The present interpretation, however, gives rise to other systemic doubts. Acknowledging the primacy of EC law over domestic law whilst refusing a similar peculiarity to the Convention can be a non-convincing solution given that the Convention in turn could prevail on the EC law due to its fundamental nature. ${ }^{132}$

\section{K. Conclusions}

In light of the considerations made so far, it is worthwhile to now propose a few final thoughts that could help us to understand the potential impact these decisions could have in the near future.

The Constitutional Court decided to support the openness of the Italian legal system to the international law universe, but it seemed to do so using a strictly domestic device, such as the introduction of a middle step in the source hierarchy, as we have been trying to explain. This attempt reflected the complexity of the decisions' reasoning, and underlined how a definitive choice between the formalistic approach and the axiological one has not been made yet.

The Court took avail of these decisions to finally clarify the real meaning of Article 117, par. 1 of the Constitution, and therefore carved out a decision which would work as a model for the future dynamics of the relationship between national (both regional and State) and supra-national norms, and as a memorandum for the Courts involved in the management of such normative network, each at the relevant level. The willingness of establishing general rules ended up losing touch with the case at stake: it could be argued that the ECvHR deserved a different treatment from the other sources of international law; both because of its very nature, and because of the unique features of the judicial system it is attached to (most of all, the enforceability of the ECtHR's rulings).

The Court certainly decided to intervene steadily in order to contain the disapplication wave that had already started spreading among the Italian Courts, and, at the same time, it took avail of this opportunity to invent a new task for itself, that of superintending the efficacy of international law in the Italian legal order. This choice came at a price: not only did it mean a sudden stop to the merit judges that had started behaving more properly like natural judges of the Convention, but it could more generally weigh down the circulation of human rights across the systems. On the other hand, the Court acknowledged the absolute importance of the (potentially evolutionary) interpretation of the Strasbourg Court,

${ }^{132}$ See R. Conti, supra note 71, at 211. 
thus opening the way to an enriching dialogue between jurisdictions, from whose effects the overall level of protection of rights could probably benefit.

The Court is currently handling the ILO case (see above), and it will represent a good chance to verify which of the different souls of the commented decisions will prevail. Indeed, we will be able to see, respectively, the Court's position with respect to the potential prevalence of the internal provision on the conventional rule, and which criterion the Court will follow to identify the authoritative interpretation of an international source that has no official interpreter.

Moreover, another challenge will probably come "from the above:" the EU membership to the Convention will soon become reality, and it is difficult now to foresee what its effect shall be, apart from the almost peaceful consideration that the Convention will only have some influence the EU - related competences. In any case, the attempt made by the Court to limit the influence of the Convention to matters of EU law could not resist the harmonising momentum, which is gradually leading to the "merger" of the European charters of rights.

From a technical point of view, the introduction of constitutionality test run by a judicial body on the content of the Convention seems a slightly anachronistic move, and not fully justified. In fact, it seems like the enlargement of supra-national law forces domestic Courts to rule an area of absolute judicial exclusiveness that keeps constantly lessening. It is unlikely that the Court could be actually afraid to become a "regional" tribunal, but still it has to be careful if it wants to preserve and execute its powers, however, this constant re-definition of tasks could sometimes seem to endanger the role of the ordinary judge, ${ }^{133}$ especially when it consists of a centralization of tasks, rather than a partition of duties ruled by some principle of judicial subsidiarity.

In the end, the technical asperities of these decisions will be softened through the constant practical applications of the principles contained therein, and the utmost effort played by the Italian Constitutional Court to open the Italian legal order to the case-law of the ECtHR (that is, the overcoming of a formalistic understanding of the Convention) is a decisive step towards the definite abandonment of the counterlimits rhetoric at least if, as we assume, the proclaimed possibility to "review" the Convention will remain dead letter.

${ }^{133}$ The choice made in the decision No. 39/2008 mentioned above could give rise to similar doubt. The Court therein seemed to prevent ordinary judges from taking the initiative and from taking possession of the "conventionality test" too early; in fact, the Constitutional Court gave the good example, showing how a careful understanding of the Strasbourg jurisprudence can facilitate the prevalence of the Convention on the domestic provisions. 
